\title{
Review on Power Performance and Efficiency of Wave Energy Converters
}

\author{
Tunde Aderinto ${ }^{1}$ and $\mathrm{Hua} \mathrm{Li}^{2, *}$ \\ 1 Sustainable Energy Systems Engineering, Texas A\&M University-Kingsville, Kingsville, TX 78363, USA; \\ tunde.aderinto@students.tamuk.edu \\ 2 Mechanical and Industrial Engineering Department, Texas A\&M University-Kingsville, \\ Kingsville, TX 78363, USA \\ * Correspondence: hua.li@tamuk.edu; Tel.: +1-361-593-4057
}

Received: 22 October 2019; Accepted: 6 November 2019; Published: 13 November 2019

\begin{abstract}
The level of awareness about ocean wave energy as a viable source of useful energy has been increasing recently. Different concepts and methods have been suggested by many researchers to harvest ocean wave energy. This paper reviews and compares the efficiencies and power performance of different wave energy converters. The types of analyses used in deriving the reported efficiencies are identified, and the stage of the power conversion processes at which the efficiencies were determined is also identified. In order to find a common way to compare the efficiencies of different technologies, the hydrodynamic efficiency in relation to the characteristic width of the wave energy converters and the wave resource potential are chosen in this paper. The results show that the oscillating body systems have the highest ratio in terms of the efficiency per characteristic width, and overtopping devices have the lowest. In addition, with better understanding of the devices' dynamics, the efficiencies of the newer oscillating water column and body systems would increase as the potential wave energy level increases, which shows that those newer designs could be suitable for more potential locations with large variations in wave energy potentials. At last, discussion about the cost of ocean wave energy is presented as well.
\end{abstract}

Keywords: wave energy converters; power performance; efficiency

\section{Introduction}

The potential of using ocean wave energy as a useful and reliable energy source has been generally accepted. Ocean wave energy resources have been assessed at global [1-3] and regional levels [4-7], and the amount of available ocean wave energy is substantial enough to generate serious interest in exploiting it. The general consensus is that the amount of available ocean wave energy is capable of contributing significantly to the energy needs of different countries. Countries with a considerable amount of exposure to the ocean along and within their borders would benefit from the successful exploitation of the ocean wave energy. Countries in Europe, the United States of America, China, and India are at the forefront of developing strategies to add ocean wave energy into their energy mix [8]. Governmental agencies in these countries have commissioned studies to perform resource assessments [9] and provided laboratories and test sites for the design and testing of wave energy converters (WECs) [10-12]. Apart from government commissioned studies, some studies are being performed by private organizations [13], universities [14], research centers [15], and individuals, which are all participating in the quest to bring ocean wave energy into the mainstream of the renewable energy industry. As a way of encouraging research into ocean wave energy systems, the United States Department of Energy sponsored a public design-build-test competition for organizations involved in wave energy converter development [16]. Top prizes were awarded to the devices with the best 
energy harvest efficiency. The winner of the competition was "AquaHarmonics", which used fivefold technology to improve its performance [16].

Back in 2002, there were already more than 1000 different patents filed on wave energy systems around the world, as stated in [17]. Different designers, scientists, and engineers have claimed the uniqueness of their equipment in terms of the advancement of performance. However, despite these numerous attempts, the commercial exploitation of the wave energy resource has been very slow compared to renewable energy sources such as wind and solar. Many issues have been identified as factors affecting the low penetration of ocean wave energy. Challenges ranging from the variability of the ocean waves' properties and the survivability of the wave energy converters in the harsh ocean environment have been identified by different studies [18,19].

Many concepts and designs of wave energy converters have been developed over the years. Those concepts and designs that have cropped up in the wave energy industry can be categorized into three main categories, as shown in Figure 1: (1) oscillating water columns (OWCs), (2) oscillating body systems, and (3) overtopping systems. These devices can be either placed along the coastlines as fixed structures or used as floating structures in offshore areas. This main characterization of wave energy converters is based on different types of interaction between the devices and the ocean waves. Those concepts and designs aforementioned are based on combinations and modifications of the three main categories. The growth of the wave energy industry is also hampered by the lack of standard procedures and criteria related to choosing suitable technology among the three main categories to harvest wave energy at different locations. It is also difficult to quantify the progress of the advancement in wave energy-harvesting techniques, even though many researchers have claimed to improve existing concepts and designs.
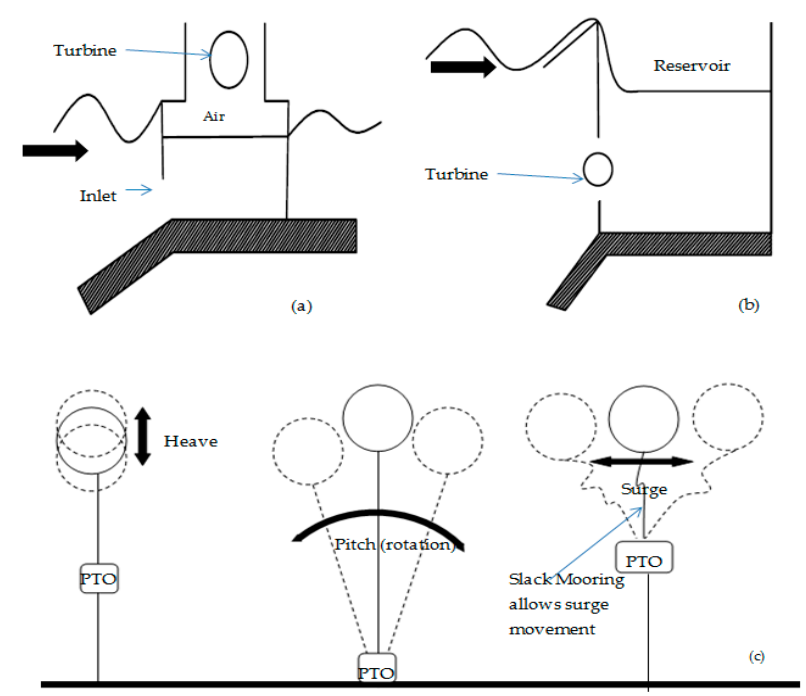

Figure 1. Classification of wave energy converter (WEC) extraction technology: (a) oscillating water column, (b) overtopping devices, and (c) oscillating bodies.

The first recorded patent filed on wave energy harvest was in 1799 using the oscillating water column technology [20]. The device was reported to supply a home with about $1 \mathrm{~kW}$ of electricity. Between this period and the early 1960s, no serious activity on wave energy systems was recorded. The WEC system put in place by Y. Masuda [21] was used to provide power for ocean buoys in the late 1960s to early 1970s. A larger device named Kaimei was developed later by Masuda. This device housed and tested several OWCs equipped with different types of air turbines. However, its power output performance was not good since it was still at an early stage when the theoretical knowledge of wave energy absorption was in its infancy. With the increase in the theoretical knowledge of wave-structure interactions, improvements were made on Masuda's basic design, which led to the design and installation of two full-size devices in Norway with rated capacities of $350 \mathrm{~kW}$ and 
$500 \mathrm{~kW}$, respectively [21] in 1985. By the early 1990s, a prototype rated at $75 \mathrm{~kW}$ was installed along the shores of Scotland [22], while a prototype rated at $60 \mathrm{~kW}$ was installed in Japan [23], and one rated at $120 \mathrm{~kW}$ was installed in India [24]. It should be noted that all these highlighted values of power are the designed rated capacity of the devices.

To properly measure the growth of the wave energy industry, it is necessary to determine the capacities of those early wave energy-harvesting devices and compare them with the capacities of recent similar devices. This should be done by investigating not only the rated power capacity of these devices, but also the actual power production either proposed or tested. There exists few guidelines on how to estimate the performance of wave energy converters; hence, it is difficult to ascertain claims of improvement by different researchers. Moreover, there exist different technology directions for the harvesting, so it may be difficult to evaluate and compare their power performance. There have been some attempts by researchers to quantify the power produced by their devices. For example, while some researchers have used the absorbed power versus the rated power of the device power performance of OWC devices, others have estimated the power through the hydrodynamic performance of a system, which is based on the ratio of absorbed power to the power available in the interacting wave front [25-27]. In some cases, the performance of the absorber was treated separately from that of the power take-off when estimating the power performance [27].

The aim of this paper is to review the performance trends of different wave energy converters during the past 30 years. Thirty years ago, it was the time when the first set of 'successful' WECs started coming up. This paper reviews the proposed concepts that have reached the design stage and have been deemed feasible. Experimental and simulations of WECs are also reviewed with focus on their performance. Most importantly, for WECs that have been field tested or are being operated, their performance is evaluated based on the ratio of their power output to the energy potential presented at the site. Distinctions are made on whether the reported power performance is for the whole system or for subsystems such as the absorber part or the power take-off parts. This paper first reviews the performance trends within each of the three main WEC technology categories followed by a comparison between different harvesting technologies. Although most of the studies conducted on ocean wave energy converters have focused mainly on the power capture, some recent studies have also focused on analyzing the costs at which wave energy can be harvested. The relationship between costs and power performance is not independent. As such, technology improvement focused on increasing power capture may lead to a decrease in costs, thereby increasing the competitiveness of ocean wave energy with other energy sources.

\section{Performance Analysis of Wave Energy Converters}

There are different ways to account for the performance of wave energy converters. A specific index or multiple indices may be used to describe the performance of a WEC. For example, a notable recent work [28] that uses power performance to describe different wave energy converters chose the capture width ratio as the basis for power performance comparison among different wave energy converters. Another work [29] focused on the economic aspect while comparing WECs, using the levelized cost of producing $1 \mathrm{kWh}$ of energy and assessing their competitiveness and profitability. Factors influencing the costs were included in the analysis, which include construction and installation, operation and maintenance, etc.

The analysis and comparison of WECs' performance can be problematic. This paper has identified three critical challenges as listed below, and created a framework to incorporate and address these challenges to form a reasonable comparison between different types of WECs.

1. Since there are many different capture technologies of WECs available, it may difficult to compare the performance of different technologies at the same time.

2. The scales and sizes of different wave energy converters will affect the comparison results. Therefore, in comparing similar WECs at different model sizes, a scaling ratio needs to be defined for different model sizes as well as the wave conditions in which those models were tested. 
For example, a laboratory-scaled WEC will probably be dominated by inertia forces instead of gravity forces since its size is usually small, while gravity forces may become dominated for a prototype scaled model tested in the field due to the increased size [30]. Furthermore, since a laboratory scaled model will probably contain fewer parts such as the power take-off (PTO), electrical, and transmission systems, the impacts on the WEC's efficiency associated with these parts may make the results of simulation and laboratory scaled devices tests different from the results of field prototypes tests and the operating WECs.

3. The performance of WECs can be greatly influenced by the wave condition at the test sites. For example, the performance of oscillating water columns and oscillating body systems, whose optimum capture occurs when the WEC is at resonance with the incoming waves [31-35], will be much lower if the WECs are tested in a site where most of the wave properties are outside the WEC's resonance bandwidth.

To account for these identified challenges related to providing a reasonable comparison while tracking the trends in each WEC's performance, research in comparison analyses conducted by some scholars provides some solutions to tackle these challenges. Rusu et al. [26] compared the performance of different WECs including the most developed ones at selected test sites around the world. The parameters used for the comparison include (1) the power matrix $\left(P_{E}\right)$ defined by the device manufacturer based on the bivariate distribution of significant wave height and peak period; (2) the capacity factor, which is defined as the relationship between $P_{E}$ and the actual power captured under different wave conditions; and (3) the ratio of $P_{E}$ and the theoretical power potential available in the area per unit of wave front defined by the capture width [25]. This method described above is very good for comparing WECs or WEC concepts when the dimensions, technology types, and wave properties of intended/installed sites are well defined; thus, it is chosen to be used in this review paper. For WEC concepts that lack detailed parameters, it is assumed that the device is operated in optimum conditions as described by WEC concepts.

Considering the three major challenges described above, the framework adopted for the hydrodynamic power efficiency comparison in this paper is the ratio of the power capture to that of the power available within the width of the primary interacting part of the device.

$$
\text { Efficiency }(\eta)=\frac{\text { Power Absorbed }}{\text { Power available within device width }}
$$

Using this method to estimate the power absorbing efficiency is almost straightforward for WECs in oscillating water columns and oscillating body systems categories. Even when the devices have irregular shapes, the width of the device that interacts with the ocean waves is usually well defined. For overtopping devices, there is a big challenge when using this method because their mode of operation is more similar to that of conventional hydropower systems technically. In addressing this challenge, a modified method is used to estimate the hydrodynamic performance of overtopping converters, in which the hydrodynamic efficiency is represented by the ratio of power in the crest of the overtopping water after it encounters the converter to that of the power available in the ocean waves. The power in the crest of the overtopping device will depend on the width as well as the depth between the top and the turbine. This method may be able to give an estimate of the amount of average power absorbed from the power available in ocean waves during a specific period of time by the overtopping devices.

The established ocean wave test sites around the world have provided researchers and developers access to quality wave energy resource potential data as well as facilities to test their designs, models, and prototypes. The ocean wave resources at these testing sites (as listed in Table 1) have been thoroughly characterized. Hence, they give very reliable data regarding the performance of the devices tested at those sites. Table 1 shows that most of those testing sites are in Europe. The Pacific Marine Energy site that is being built in the United States is a comprehensive site that will be larger in scope than all existing testing sites, and will be able to test different types and scales of WECs. There exists other small testing facilities in the USA; however, most of these small facilities use wave tanks that are 
designed for testing smaller models of WECs [36-39]. Other planned sites include sites in Zhejiang, Guangdong, and Shandong provinces in China [40]. The efficiencies of wave energy converters can be classified by the efficiencies at the different stages of their energy conversion processes [41]:

1. Pneumatic/hydrodynamic efficiency: This is the ratio of the primary energy absorbed by the device to the energy resource available within the interacting section of the device with the ocean wave.

2. Turbine/mechanical efficiency: This is the ratio of the absorbed energy by the device to the mechanical energy through the power take-off device.

3. Electrical efficiency: This is the ratio of the mechanical energy to electrical energy in situ through the appropriate generator.

4. Transmission efficiency: This occurs during the conversion of the unstable electrical energy by the device to stable grid-acceptable electric energy.

In this review paper, the four types of efficiencies described above are used to analyze all three major types of WECs listed in Section 1. The different devices within each type are compared first (in Sections 3-5), and then all three types are compared with each other in Section 6.

There are many studies in the literature reporting the power performance of different WECs. In compiling the efficiencies of different WECs in this study, the authors only chose those that were tested or simulated using irregular wave conditions. The reported efficiencies in this paper mostly focused on the optimum power captured by the WECs. Since the WECs were designed to reach optimum performance in specific irregular wave conditions, most of the reported efficiencies in this paper represent the best performance of specific WECs, even though they were tested or simulated in different irregular wave conditions with weighted probabilities of occurrences. In some cases, the annual average performance is reported as well in this paper.

Table 1. Major Wave Energy Test Centers around the World.

\begin{tabular}{|c|c|c|c|c|}
\hline Test Center & Scale & $\begin{array}{l}\text { Wave Resource } \\
(\mathrm{kW} / \mathrm{m})\end{array}$ & $\begin{array}{c}\text { Grid } \\
\text { Connection }\end{array}$ & $\begin{array}{c}\text { Distance from } \\
\text { Shore/Water Depth }\end{array}$ \\
\hline $\begin{array}{c}\text { Danish Marine Test Site (DanWEC), } \\
\text { Denmark [42] }\end{array}$ & Full & 5 & Yes & $200 \mathrm{~m} / 12 \mathrm{~m}$ \\
\hline Wave Hub, England [43] & Full & 20 & Yes & $16 \mathrm{~km} / 55-65 \mathrm{~m}$ \\
\hline SEM-REV, France [44] & Full & 15 & Yes & $15 \mathrm{~km} / 35 \mathrm{~m}$ \\
\hline $\begin{array}{c}\text { Atlantic Marine Energy Test site, } \\
\text { Ireland }[45,46]\end{array}$ & Full & $\begin{array}{l}* 70-75 \\
* * 55-60\end{array}$ & Yes & $\begin{array}{l}* 10 \mathrm{~km} / 100 \mathrm{~m} \\
* * 6.5 \mathrm{~km} / 50 \mathrm{~m}\end{array}$ \\
\hline Runde Island, Norway [47] & Full & NA & Yes & $500 \mathrm{~m} / 30-35 \mathrm{~m}$ \\
\hline Pilot zone, Portugal [48] & Full & 32 & Yes & $5-8 \mathrm{~km} / 30-90 \mathrm{~m}$ \\
\hline $\begin{array}{l}\text { European Marine Energy Centre } \\
\text { (EMEC), Scotland [49] }\end{array}$ & Full & $22-25$ & Yes & $1-2 \mathrm{~km} / 20-75 \mathrm{~m}$ \\
\hline $\begin{array}{l}\text { Biscay Marine Energy Platform } \\
\text { (Bimep), Spain [50] }\end{array}$ & Full & 21 & Yes & $1.7 \mathrm{~km} / 50-90 \mathrm{~m}$ \\
\hline Plocan, Canary Islands, Spain [51] & Full & $8-10$ & Yes & $2 \mathrm{~km} / 30-1000 \mathrm{~m}$ \\
\hline Nissum Bredning, Denmark [52] & $1: 4-1: 10$ & $\mathrm{H}_{\mathrm{s}}=1.2 \mathrm{~m}$ & Yes & $200 \mathrm{~m} / 4-10 \mathrm{~m}$ \\
\hline $\begin{array}{c}\text { The Galway Bay Wave Energy Test } \\
\text { Site, Ireland [53] }\end{array}$ & $1: 3-1: 5$ & 3 & No & $2.4 \mathrm{~km} / 21-24 \mathrm{~m}$ \\
\hline $\begin{array}{l}\text { European Marine Energy Centre } \\
\text { (EMEC), Scotland [49] }\end{array}$ & $1: 10$ & $\mathrm{H}_{\mathrm{S}} \sim 0.35 \mathrm{~m}$ & Yes & $500 \mathrm{~m} / 21-25 \mathrm{~m}$ \\
\hline Famouth Bay test site, England [54] & $\mathrm{N} / \mathrm{A}$ & $\mathrm{N} / \mathrm{A}$ & No & $3-5 \mathrm{~km} / 20-50 \mathrm{~m}$ \\
\hline $\begin{array}{l}\text { Pacific Marine Energy Centre } \\
\text { USA }[55,56]\end{array}$ & $\begin{array}{l}\text { Full, } \\
\text { Large, } \\
\text { Small }\end{array}$ & $>15 \mathrm{~kW} / \mathrm{m}$ & Yes & $\begin{array}{c}16 \mathrm{~km} / \text { Several meters } \\
\text { over } 100 \mathrm{~m}\end{array}$ \\
\hline $\begin{array}{l}\text { The Hawai'i Wave Energy Test Site } \\
\text { (WETS), USA [57] }\end{array}$ & Large & N/A & No & $\mathrm{N} / \mathrm{A}$ \\
\hline Shandong Test Site, China [58] & Large & $4 \mathrm{~kW} / \mathrm{m}$ & Yes & $30 \mathrm{~m}$ \\
\hline
\end{tabular}




\section{Oscillating Water Column Devices}

Commercialized ocean WECs were first reported in the 1960s, when they were used to power navigation buoys in Japan and the USA [59]. Although those WECs were not termed as oscillating water columns (OWCs) then, their capturing technology was later identified as close to that of the OWCs. Another larger floating device measuring up to $80 \mathrm{~m}$ containing several devices with different air turbines was tested in 1976 by the same designer [60]. Although little information was known about the performance of those devices, the general consensus among scholars was that their performance was low [21]. One of the reasons suggested for this low performance is that vigorous studies into WEC's behavior were still scarce at that stage. Despite these setbacks, Masuda $[59,60]$ has demonstrated that ocean waves could supply a reliable source of energy. Following more theoretical analyses into wave energy dynamics [29-31], the 1980s and the early 2000s saw many bold attempts regarding the design and construction of WEC prototypes around the world. The capacities of those major WECs and their prototypes ranged from tens of $\mathrm{kW}$ to several hundreds of $\mathrm{kW}$, as shown in Table 2 . When these devices were first deployed, the only information available was their name plate capacity. After some years of studying and testing, they were accessed in different ocean wave environments. Simulation and numerical studies were performed on models of the devices, while optimization methods were developed to develop better power take-off to increase efficiency. These studies increased the knowledge of the performance of different types of oscillating water columns.

Table 2. Some major oscillating water column (OWC) devices and their name plate capacities.

\begin{tabular}{ccc}
\hline Name/Location & Capacity & Comments \\
\hline KVAENER/Norway [61,62] & $500 \mathrm{~kW}$ (Operation) & N/A \\
Japan [23] & $60 \mathrm{~kW}$ & Prototype \\
LIMPET/Scotland [63,64] & $75 \mathrm{~kW}$ prototype, ${ }^{*} 500 \mathrm{~kW}$ & $*$ Downgraded to 250 kW later \\
operated & N/A \\
India [24,65] & $150 \mathrm{~kW}$ & N/A \\
Pico/Portugal [66-69] & $400 \mathrm{~kW}$ & N/A \\
Australia [70,71] & $450 \mathrm{~kW}$ & N/A units with 18.5 kW each \\
Mutriku Spain [72,73] & $296 \mathrm{~kW}$ & N/A \\
Mighty Whale [74] & $110 \mathrm{~kW}$ & Non \\
KRISO/South Korea [75] & $500 \mathrm{~kW}$ &
\end{tabular}

\subsection{Simulation and Numerical Analysis on Oscillating Water Columns}

When the first set of OWC prototypes were deployed, the numerical and analytical understanding of those devices' dynamics were very limited. In addition, the availability of power computational fluid dynamics applications was also limited. Hence, most simulation analyses of the OWCs using computational tools were performed in and after the 2000s. These computational fluid dynamics (CFD) codes were based on the numerical integration of Reynolds-averaged Navier-Stokes (RANS) equations. Simulations were performed, and the simulation results were compared with results obtained from the prototype tests [76-78]. Some simulations and numerical analyses were performed in conjunction with laboratory-scaled tests for validation purposes $[69,74,79]$. The latest sets of simulation were performed to study existing devices and to help increase the efficiency of the existing devices through optimization. The simulation and numerical results provided better understanding of the existing testing results from deployed devices, and the efficiency and performances of these existing OWCs. Therefore, optimizations and modifications to improve the efficiency of the devices can be incorporated at the design stage through simulations and numerical analysis. Some of the important simulations and numerical analyses made on the existing and generic OWCs are summarized in Table 3. 
Table 3. Efficiencies of Selected OWCs based on Simulation and Numerical Analysis Results.

\begin{tabular}{|c|c|c|c|}
\hline ID & Scale of Wave Data & Efficiency & Comments \\
\hline 1 & Laboratory [80-82] & $\begin{array}{l}\text { Information not } \\
\text { available }\end{array}$ & $\begin{array}{c}\text { Simulation and numerical analysis done to } \\
\text { verify lab tests }\end{array}$ \\
\hline 2 & $\begin{array}{c}36 \text { sea states at the } \\
\text { Canadian Pacific site [83] }\end{array}$ & $11.6 \%$ & $\begin{array}{c}\text { Annual, pre-design analysis including } \\
\text { pneumatic, mechanical, and electrical } \\
\text { efficiency }\end{array}$ \\
\hline 3 & $\begin{array}{l}\text { Real sea state at Monte } \\
\text { Redondo in Chile [84] }\end{array}$ & $\begin{array}{l}(\text { a) } * 40.87 \% \\
\text { (b) } * * 24.42 \% \\
\text { (c) } * * * 17.9 \%\end{array}$ & $\begin{array}{l}* \text { Rectangular cross-section }(6.0 \mathrm{~m} \text { by } 12 \mathrm{~m} \text { ) } \\
* * \text { Circular cross-section (radius }=7.6 \mathrm{~m}) \\
* * * \text { Circular cross-section (radius }=6.77 \mathrm{~m} \text { ) } \\
\text { Only pneumatic efficiency calculated }\end{array}$ \\
\hline 4 & $\begin{array}{l}14 \text { sea states on the western } \\
\text { coast of Portugal [85] }\end{array}$ & $2 \%$ & Simulation + geometric optimization of OWC \\
\hline 5 & Pico Wave site [86-88] & $\begin{array}{c}* 10 \% \\
\text { (b) } * * 31 \%[87,88]\end{array}$ & $\begin{array}{c}{ }^{*} \text { Increase in efficiency by using control valves } \\
{ }^{* *} \text { Average annual output vs. rated power of } \\
\text { air turbine }\end{array}$ \\
\hline 6 & Laboratory [89] & N/A & $\begin{array}{l}\text { Geometry optimization. Maximum efficiency } \\
\text { occurs when the ratio of the cross-sectional } \\
\text { areas of the orifice and the air chamber }=0.66 \\
\text { (pneumatic efficiency) }\end{array}$ \\
\hline 7 & Laboratory [90] & $45 \%$ & Pneumatic efficiency \\
\hline 8 & Laboratory [91] & $* 71 \%$ & $\begin{array}{l}\text { Geometry optimization: Bottom profile } \\
\text { * Instantaneous peak value at resonance for a } \\
\text { circular bottom profile }\end{array}$ \\
\hline 9 & $\begin{array}{l}\text { (a) Sea states @ western } \\
\text { coast of Portugal [92] } \\
\text { (b) Sea states @ western } \\
\text { coast of Portugal [93] }\end{array}$ & N/A & $\begin{array}{c}\text { (a) Shape optimization. Almost sixfold } \\
\text { increase in pneumatic efficiency claimed } \\
\text { (b) Geometry optimization of device and } \\
\text { turbine optimization } 50 \% \text { increase in electrical } \\
\text { energy }\end{array}$ \\
\hline 10 & $\begin{array}{l}\text { Sea states from Italian } \\
\text { coast [94] }\end{array}$ & $* 15 \%$ & $\begin{array}{l}\text { Turbine optimization } \\
{ }^{*} \text { Increase in electrical efficiency }\end{array}$ \\
\hline
\end{tabular}

\subsection{Efficiencies of Large-Scale Prototypes and Field Tests Results of OWCs}

The progress made in the understanding of OWC devices stemmed from the fact that some full-scale prototypes of these devices were manufactured, installed, and operated. The operation of these prototypes provided much more insight into the dynamics of their energy conversion processes and performances. The major successful OWC devices are the Pico [46,47], Mighty Whale [74,76,77], LIMPET [63,64], and Mutriku [72,73]. These devices were operated for long periods, so their performances has been well documented in many research studies. Meanwhile, these prototypes have been tested at the model scale in wave tanks for optimization studies and performance assessments. The wave tank models provided better results that can be used to validate simulation analysis. The performance of these prototypes and the models installed around the world are summarized in Table 4 . To be consistent, the IDs of all the devices were continuously numbered in the paper, which was also easier for representing the devices in the figures later.

Table 4. Efficiencies of Wave Tanks and Sea Trials Performed on Selected OWCs.

\begin{tabular}{|c|c|c|c|c|}
\hline ID & Type & Scale & Efficiency & Comments \\
\hline 11 & Spar Buoy [95] & 1:7 (Wave Tank) & N/A & $\begin{array}{l}\text { Aimed to use control strategy to } \\
\text { increase turbine efficiency }\end{array}$ \\
\hline 12 & Generic OWC [96] & 1:50 (Wave tank) & $\sim 30 \%$ & From pneumatic to mechanical stage \\
\hline 13 & Generic OWC [97] & 1:50 (Wave tank) & $\begin{array}{l}* \sim 30 \% \\
* * \sim 7.5 \%\end{array}$ & $\begin{array}{l}{ }^{*} \text { Mechanical efficiency } \\
{ }_{* *} \text { Electrical efficiency }\end{array}$ \\
\hline 14 & Mighty Whale [74] & 1:1 Sea trials & $\begin{aligned} * & \sim 5 \% \\
* * & \sim 15 \%\end{aligned}$ & $\begin{array}{l}\text { * Mechanical efficiency } \\
* * \text { Electrical efficiency }\end{array}$ \\
\hline 15 & Swank DK3 [98] & N/A & $20 \%$ & Pneumatic efficiency \\
\hline
\end{tabular}


Table 4. Cont.

\begin{tabular}{ccccc}
\hline ID & Type & Scale & Efficiency & Comments \\
\hline 16 & Mutriku [72] & 1:40 (Wave tank) & $7 \%$ & Pneumatic efficiency \\
17 & Pico [99] & $1: 1$ Sea trials & $20 \%$ & Pneumatic efficiency \\
18 & Lanchester & Wave tank & $23 \%$ & Pneumatic efficiency \\
\hline
\end{tabular}

\section{Oscillating Body Systems}

Oscillating body systems are also referred as wave-activated body systems. This is because their main mode of operation involves the generation of oscillatory motion by the body during its interaction with the ocean waves. This motion is converted to other forms of useful energy through the appropriate power take-off mechanism. Most oscillating body systems are heaving and pitching devices with the main absorbing systems floating on the water surface. In few reported cases such as the famous Archimedes wave spring (AWS), they can also be submerged bodies [101]. Unlike oscillating water column devices, which can be mounted along the coastlines or in shallow waters, oscillating body systems require areas with adequate depth depending on the size and type of the WEC to cater for the motions of the body. The complexities associated with offshore structures make the deployment of wave-activated systems more challenging. With the increase in the knowledge of the dynamics of floating bodies, there has been an increase in the study of the capture mechanism of oscillating body systems. One major thing that makes the use of these types of converters attractive is that the efficiency of the energy absorbed by the body can be improved significantly when the body is at resonance with the incoming wave (Figure 2).

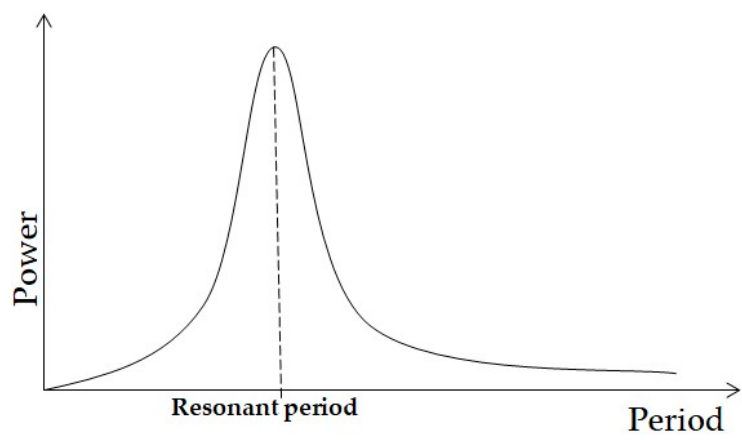

Figure 2. Theoretical Power Capture of Oscillating Body System Converter.

The main oscillating systems are the heaving systems and the oscillating surge converters/pitching systems or a hybrid of these two systems. For most of these devices, all degrees of motion can usually occur during operation; however, the motion directions needed for power capture are allowed, while the remaining motion directions are usually restrained. The dimensions and configurations of the devices are usually designed in such a way to make the motion in the desired direction more prominent. Over the years, different methods have been used to increase the overall efficiencies of the oscillating body systems. Due to the dynamics of floating bodies, the methods to increase the efficiencies are mainly focused on making the energy absorbing part operate around its resonant period. The major challenge is that the real ocean wave environment is random in nature. Hence, tuning the oscillating body systems to resonate with different ocean waves frequency is a problem. The most common methods used are the active and passive control methods through the use of power take-off as well as optimization of the geometry. Other methods include the reduction of the viscous damping that occurs during the movement of the buoy inside the water [102]. 


\subsection{Active and Passive Control to Increase Efficiency}

Active controls differs from passive controls. In active control, power has to be supplied either externally from the produced power by the WEC for controlling the primary wave energy absorber $[103,104]$, while latching and declutching are examples of the passive control methods of a WEC, and are very common in WEC optimization studies $[105,106]$. Latching control is achieved by holding the heaving WEC in a fixed position when the velocity is zero and releasing the WEC at the right time so that its velocity can be in phase with the excitation force, so that resonance is achieved [107]. On the other hand, declutching works by alternatively switching the power take-off system on and off [108]. It is also called unlatching. Many researchers [109,110] have reported increases in power capture through this method. The work on the special latching and declutching method to control the converter using active reference [111] described an in situ actively controlled motion compensated platform that acts as an active reference in the latching of a hemispherical-shaped device. The major limitation of the latching and declutching method, especially for heaving systems, is that it cannot be used for direct drive linear generators or on arrays of converters, because the optimum phase for latching will be different for each of the oscillators present in the array [112].

\subsection{Geometric Optimization to Increase Efficiency}

The work done by [113] applied a geometrical optimization method to a heaving point absorber WEC using the statistical method coupled with a frequency domain hydrodynamics of the system based on data from the coast of Rio De Janiero. Their work focused on maximizing the power absorbed by the WEC through matching its geometry to resonate close to the dominant wave period during the sea test. The statistical analysis through the design of experiment (DOE) method reduced the computational time, because the optimum geometry to capture the maximum power was quickly determined. Another study [114] on the geometry optimization used wave data from the Atlantic Marine test site situated in Ireland. The researchers tried to maximize the dynamic heave velocity response of the unconstrained system. In this work, different shapes of the heaving buoy were considered, and the optimum geometry was determined to be the one that yielded the maximum dynamic velocity, which was considered the most suitable. Changes to the inertia during experiments of a laboratory-scaled converter were performed by [115]. The inertia of the device was adjusted in order for its natural frequency to resonate with different frequency bandwidths of an irregular wave. Although their experiments used metal weights to adjust the inertia in the laboratory, they suggested that ballasting and deballasting could be employed on real converters at sea. The conclusion of their work estimated an increase of power capture between $15 \%$ and $25 \%$ when compared with that of a static inertia. Another important study on the shape optimization of WECs was performed by [116], where the optimum shape under monochromatic (unidirectional and multidirectional) and polychromatic (unidirectional and multidirectional) ocean waves were analyzed. A genetic algorithm was used to search through a wide range of shapes, and the optimum shape was investigated under different ocean wave conditions. Optimization of the geometry, mooring line, and mass distribution of a point absorber-heaving WEC was performed by [117]. This was done in a frequency domain analysis by representing the irregular waves through a superposition of regular waves. They also examined the safety of the WEC tested at the site. The WEC was tuned to the site-specific wave characteristics to optimize the power capture. A more rigorous work that considered the buoy geometry, dimensions, mass of the moving parts, damping force of the generators, connected load, and velocity of the buoys was done by Sjokvist et al. [118]. They created a parameter (velocity ratio) to determine the relationship of the draft and buoy radius with the motion and energy absorption of the WEC. They used this relationship to determine the optimum buoy geometry suitable for power absorption.

The main challenges facing the optimization methods of a WEC's geometry and inertia is that most are only suitable for a narrow bandwidth of ocean wave frequency. Hence, most of these devices are tuned to the predominant ocean wave properties. Their power performance outside the frequency bandwidth is very low. 


\subsection{Heaving Systems}

Heaving systems transmit energy to a power take-off mechanism through the vertical oscillatory motion of the device, which acts as a piston. The simplest configuration consists of a vertically oscillating buoy connected to a fixed foundation $[119,120]$. Other configurations are the multibody systems [121,122]. Different methods of designs have been used to improve the performance of the different heaving systems. Their simple configuration has made them attractive for use by different developers. For example, heaving wave energy devices are presently tailored to cater for offshore energy needs such as communication, oil and gas, ocean data gathering, and monitoring, among others [123].

The efficiencies of different heaving wave energy converters reported through simulations, experimental trials, and sea trials over the years are shown in Table 5. The efficiencies reported are selected based on the comprehensive approach to which the efficiencies were derived. All the reported efficiencies, whether based on simulations, model tests, or sea trials were made with real wave data. In addition, for devices tested in [11,124-128], the devices are modeled similar to existing systems that have been validated. For example, the systems described in $[122,123,126]$ are modeled according to the SEACAP WEC device, OPT buoy device, and Wavestar WEC, respectively. The efficiencies and the wave energy potentials reported in these devices are yearly average values. The work done in [129] also tested the devices in different regions with different wave resource potentials. It is evident that the efficiencies of the heaving devices changes when the site conditions change.

Table 5. Efficiencies of Selected Heaving WEC Systems.

\begin{tabular}{|c|c|c|c|c|c|}
\hline ID & Name/Type & Scale & $\begin{array}{c}\text { Wave Energy } \\
\text { Potential }\end{array}$ & Efficiency & Comment \\
\hline 1 & $\begin{array}{l}\text { Single cylindrical } \\
\text { body [124] }\end{array}$ & Simulation & $\begin{array}{l}26 \mathrm{~kW} / \mathrm{m}(\text { Yeu } \\
\text { test Site })\end{array}$ & $\begin{array}{l}\text { (a) } 4 \% \\
\text { (b) } 3 \% \\
\text { (c) } 6 \% \\
\text { (d) } 6 \% \\
\text { (e) } 9 \%\end{array}$ & $\begin{array}{c}\text { Hydrodynamic efficiency of } \\
\text { devices with five different } \\
\text { widths }\end{array}$ \\
\hline 2 & $\begin{array}{l}\text { Single cylindrical } \\
\text { body [125] }\end{array}$ & Simulation & $\begin{array}{c}40 \mathrm{~kW} / \mathrm{m} \\
\text { (Oregon site) }\end{array}$ & $19 \%$ & Hydrodynamic efficiency \\
\hline 3 & DEXA WEC [126] & $\begin{array}{l}\text { Model scale 1:30 } \\
\text { (width } 0.81 \mathrm{~m} \text { ) }\end{array}$ & $\begin{array}{l}26 \mathrm{~kW} / \mathrm{m}(\mathrm{Yeu} \\
\text { test Site })\end{array}$ & $8 \%$ & $\begin{array}{l}\text { Model was extrapolated to a } \\
\text { device of } 22 \text { m width. } \\
\text { Hydrodynamic efficiency }\end{array}$ \\
\hline 4 & Lifesaver [127] & $\begin{array}{l}\text { Simulation and } \\
\sim 1 \text {-year sea trial }\end{array}$ & $26 \mathrm{~kW} / \mathrm{m}$ & $12 \%$ & Hydrodynamic efficiency \\
\hline 5 & $\begin{array}{l}\text { Multibody } \\
\text { system [128] }\end{array}$ & Simulation & Various & $\begin{array}{l}\text { (a) } 10 \% \\
\text { (b) } 15 \%\end{array}$ & Hydrodynamic efficiency \\
\hline 6 & $\begin{array}{l}\text { Single cylindrical } \\
\text { body [11] }\end{array}$ & Simulation & $34 \mathrm{~kW} / \mathrm{m}$ & $16 \%$ & Hydrodynamic efficiency \\
\hline 7 & Single body [98] & Model tests & $16 \mathrm{~kW} / \mathrm{m}$ & $14 \%$ & Hydrodynamic efficiency \\
\hline 8 & $\begin{array}{l}\text { Danish Wave Energy } \\
\text { Program System [98] }\end{array}$ & Model tests & $16 \mathrm{~kW} / \mathrm{m}$ & $30 \%$ & Hydrodynamic efficiency \\
\hline 9 & AquaBuoy [129] & $\begin{array}{l}\text { Simulation of } \\
\text { prototype sized }\end{array}$ & $\begin{array}{l}* 12 \mathrm{~kW} / \mathrm{m} \\
* * 21 \mathrm{~kW} / \mathrm{m} \\
* * * 26 \mathrm{~kW} / \mathrm{m} \\
* * * * 15 \mathrm{~kW} / \mathrm{m}\end{array}$ & $\begin{array}{l}* \text { (a) } 20 \% \\
* * \text { (b) } 17 \% \\
* * * \text { (c) } 14 \% \\
* * * * \text { (d) } 21 \%\end{array}$ & Hydrodynamic efficiency \\
\hline 10 & SeaDog [127] & $\begin{array}{l}\text { Simulation of } \\
\text { prototype sized }\end{array}$ & $\begin{array}{l}* 12 \mathrm{~kW} / \mathrm{m} \\
* * 21 \mathrm{~kW} / \mathrm{m} \\
* * * 26 \mathrm{~kW} / \mathrm{m} \\
* * * * 15 \mathrm{~kW} / \mathrm{m}\end{array}$ & $\begin{array}{l}* \text { (a) } 24 \% \\
* \text { (b) } 16 \% \\
* * * \text { (c) } 16 \% \\
* * * * \text { (d) } 21 \%\end{array}$ & Hydrodynamic efficiency \\
\hline 11 & Wavebob [129] & $\begin{array}{l}\text { Simulation of } \\
\text { prototype sized }\end{array}$ & $\begin{array}{l}* 12 \mathrm{~kW} / \mathrm{m} \\
* * 21 \mathrm{~kW} / \mathrm{m} \\
* * * 26 \mathrm{~kW} / \mathrm{m} \\
* * * * 15 \mathrm{~kW} / \mathrm{m}\end{array}$ & $\begin{array}{l}* \text { (a) } 40 \% \\
* * \text { (b) } 51 \% \\
* * * \text { (c) } 46 \% \\
* * * * \text { (d) } 45 \%\end{array}$ & $\mathrm{~N} / \mathrm{A}$ \\
\hline
\end{tabular}


Table 5. Cont.

\begin{tabular}{cccccc}
\hline ID & Name/Type & Scale & $\begin{array}{c}\text { Wave Energy } \\
\text { Potential }\end{array}$ & Efficiency & Comment \\
\hline 12 & $\begin{array}{c}\text { Two-body floating } \\
\text { System [29] }\end{array}$ & Simulation & $\begin{array}{c}* 15 \mathrm{~kW} / \mathrm{m}, \\
* * * 2 \mathrm{~kW} / \mathrm{m} \\
* * * 2 \mathrm{~kW} / \mathrm{m}\end{array}$ & $\begin{array}{c}* \text { (a) } 27 \% \\
* * \text { (b) } 29 \% \\
* * * \\
\text { (c) } 36 \%\end{array}$ & Hydrodynamic efficiency \\
& Simulation & 15 & $11 \%$ & Hydrodynamic efficiency \\
\hline 13 & $\begin{array}{c}\text { Floating buoy array } \\
\text { [29] }\end{array}$ & Simulation & 31 & $25 \%$ & Hydrodynamic efficiency \\
\hline 14 & $\begin{array}{c}\text { Two-body floating } \\
\text { buoy [130] }\end{array}$ & a. Oscillating Wave Surge and Pitching Devices. &
\end{tabular}

a. Oscillating Wave Surge and Pitching Devices.

There are actually no pure surging wave energy converter devices. The actual motion direction is the pitching motion. However, these devices are named as such because the surge motions of these devices are more noticeable to a casual observer. The rotations of these devices, which are activated by the ocean waves, are connected to the appropriate power take-off for the power conversion process. Some of these devices may be hinged to a fixed foundation — such as the Weptos [131] or the Salter's duck [132]—or as a floating device such as the Pelamis [48] or SEAREV [133]. These devices have been tested at the laboratory scale up to full-scale models while being validated by numerical and simulation analyses. The Pelamis went on to become one of the few devices for which serious attempts were made at commercialization. For example, the development of the Weptos went through a carefully designed development including design, laboratory tests, wave tank tests, and sea trials, in which the ocean wave resource was evaluated and the model tests were scaled so that performance could be properly tracked. The performance and efficiencies of the major pitching devices are summarized in Table 6. All the efficiencies reported in the table are hydrodynamic efficiencies. The devices described in [132-144] in Table 6 are fixed devices, since they are usually hinged to a fixed frame of reference, while the rest of the devices in Table 6 are floating systems.

Table 6. Efficiencies of Selected Pitching WEC Systems.

\begin{tabular}{|c|c|c|c|c|c|}
\hline ID & Name/Type & Scale & $\begin{array}{l}\text { Wave Energy } \\
\text { Potential }\end{array}$ & Efficiency & Comment \\
\hline 1 & $\begin{array}{c}\text { Salter's } \\
\text { Duck [132] }\end{array}$ & $\begin{array}{l}\text { Full-scale } \\
\text { experiments and } \\
\text { simulation }\end{array}$ & $\begin{array}{l}* 16 \mathrm{~kW} / \mathrm{m} \\
* * 23 \mathrm{~kW} / \mathrm{m} \\
* * * 27 \mathrm{~kW} / \mathrm{m} \\
* * * * 38 \mathrm{~kW} / \mathrm{m}\end{array}$ & $\begin{array}{l}\text { (a) } * 65 \% \\
\text { (b) }{ }^{* *} 75 \% \\
\text { (c) } * * 79 \% \\
\text { (d) } * * * * 68 \%\end{array}$ & $\begin{array}{l}\text { Analysis performed with } \\
\text { optimal and reactive control of } \\
\text { the device } \\
\text { Width of device is } 30 \mathrm{~m}\end{array}$ \\
\hline 2 & $\begin{array}{l}\text { Top Hinged } \\
\text { Flap [134] }\end{array}$ & $\begin{array}{l}\text { Full-scale } \\
\text { simulation }\end{array}$ & 25 & $25 \%$ & Width of device is $12 \mathrm{~m}$ \\
\hline 3 & Biopower [135] & $\begin{array}{l}\text { Full-scale } \\
\text { simulation }\end{array}$ & $\begin{array}{l}{ }^{*} 10 \mathrm{~kW} / \mathrm{m} \\
* * 67 \mathrm{~kW} / \mathrm{m}\end{array}$ & $\begin{array}{c}\text { Average } \\
45 \%\end{array}$ & $\begin{array}{l}\text { * Summer resource potential } \\
\text { ** Winter resource potential } \\
\text { Width of device is } 6.6 \mathrm{~m}\end{array}$ \\
\hline 4 & $\begin{array}{c}\text { Based on } \\
\text { Oyster [136] }\end{array}$ & Wave tank & NA & $35 \%-65 \%$ & Width of device is $6 \mathrm{~m}-24 \mathrm{~m}$ \\
\hline 5 & $\begin{array}{c}\text { Weptos } \\
{[131,137,138]}\end{array}$ & Various & $\begin{array}{l}\text { 6-29 kW/m } \\
\text { (Different test } \\
\text { sites) }\end{array}$ & $12 \%-32 \%$ & $\begin{array}{l}\text { Width ranged from } 2.9 \mathrm{~m}-9.6 \mathrm{~m} \\
\text { (development program of the } \\
\text { Weptos WEC from lab testing, } \\
\text { prototype testing to sea trials }\end{array}$ \\
\hline 6 & $\begin{array}{c}\text { Offshore } 1 \\
\text { (Weptos) [139] }\end{array}$ & Sea trials & & Up to $57 \%$ & $\begin{array}{l}\text { Efficiency achieved when period } \\
\text { is about } 2 \mathrm{~s}\end{array}$ \\
\hline 7 & Weptos [140] & Simulations & $4.38 \mathrm{~kW} / \mathrm{m}$ & $50 \%-57 \%$ & $\begin{array}{c}\text { Efficiency when period is } \\
\text { 2.9-3.4 } \mathrm{s} .10 \text { rotors/side Active } \\
\text { width }=30 \mathrm{~m}, \mathrm{I} \text { rotor }=3 \mathrm{~m} \\
\text { width }\end{array}$ \\
\hline 8 & $\begin{array}{c}\text { Variant of } \\
\text { Oyster [141] }\end{array}$ & Simulations & $26 \mathrm{~kW} / \mathrm{m}$ & $\begin{array}{l}\text { (a) } * 22 \% \\
\text { (b) } * * 40 \% \\
\text { (c) }{ }^{* *} 15 \%\end{array}$ & $\begin{array}{l}\text { * Width } 6 \mathrm{~m} \\
* * \text { Width } 12 \mathrm{~m} \\
* * * \text { Width } 18 \mathrm{~m}\end{array}$ \\
\hline
\end{tabular}


Table 6. Cont.

\begin{tabular}{|c|c|c|c|c|c|}
\hline ID & Name/Type & Scale & $\begin{array}{l}\text { Wave Energy } \\
\text { Potential }\end{array}$ & Efficiency & Comment \\
\hline 9 & Pelamis [48] & $\begin{array}{l}\text { Simulation, } \\
\text { experiments, and } \\
\text { simulations }\end{array}$ & $\begin{array}{l}* 12 \mathrm{~kW} / \mathrm{m} \\
* * 21 \mathrm{~kW} / \mathrm{m} \\
* * * 26 \mathrm{~kW} / \mathrm{m} \\
* * * 15 \mathrm{~kW} / \mathrm{m}\end{array}$ & $\begin{array}{c}\text { (a) } * 21 \% \\
\text { (b) } * * 15 \% \\
\text { (c) }{ }^{* * *} 14 \% \\
\text { (d) } * * * 18 \%\end{array}$ & $\begin{array}{l}\text { Reports from various } \\
\text { experiments, tests, etc. }\end{array}$ \\
\hline 10 & $\begin{array}{c}\text { Langlee } \\
\text { Technology } \\
\text { [142] }\end{array}$ & Lab experiments & $16 \mathrm{~kW} / \mathrm{m}$ & $\begin{array}{l}\text { (a) } * 7 \% \\
\text { (b) } * * 9 \%\end{array}$ & $\begin{array}{l}* 25 \mathrm{~m} \text { width } \\
* * 37.5 \mathrm{~m} \text { width }\end{array}$ \\
\hline 11 & $\begin{array}{c}\text { Wave Piston } \\
\text { [143] }\end{array}$ & Simulation & $\begin{array}{c}* 12 \mathrm{~kW} / \mathrm{m} \\
* * 3.5 \mathrm{~kW} / \mathrm{m}\end{array}$ & $\begin{array}{l}\text { (a) } * 8 \% \\
\text { (b) } * * 15 \%\end{array}$ & \\
\hline 12 & SEAREV [144] & Simulation & $25 \mathrm{~kW} / \mathrm{m}$ & $\begin{array}{l}\text { (a) } * 20 \% \\
\text { (b) } * * 16 \% \\
\text { (c) } * * * 25 \%\end{array}$ & $\begin{array}{l}* 13.6 \mathrm{~m} \text { width } \\
* * 30 \mathrm{~m} \text { width } \\
* * * 30 \mathrm{~m} \text { width }\end{array}$ \\
\hline
\end{tabular}

\section{Overtopping Wave Energy Converters}

The method of capturing the ocean wave energy with an overtopping type of wave energy converters is very different from the other two methods described earlier. Overtopping devices are built in such a way that water around the crest of the ocean wave is captured into a reservoir and stored at a level above the average sea level. The water stored in the reservoir is released gradually to drive a hydraulic turbine to convert the potential energy of the stored water to useful energy. Hence, unlike the oscillating water column and the oscillating body systems, the energy captured is not due to the 'motion' of the ocean wave. The mode of capture is more similar to that which is obtained in the conventional hydroelectric power conversion systems. One of the earliest overtopping devices is the Tapered Channel Wave Power Device (Tapchan) in Norway [145]. It has a rated power of $350 \mathrm{~kW}$. Another popular device is the Wavedragon built in Denmark [146], which is a floating device. Similar in design to the Wavedragon is the Seawave slope cone generator [147].

The performance and capacity factors of overtopping devices will surely depend on the availability of water in the reservoir. Elevating the difference in the height between the reservoir and the free water surface is another sure way of improving the overtopping devices. In view of these factors described above, overtopping devices will be well suited for regions where the wave heights are significantly higher. The power performances of some of the popular overtopping devices over the years are summarized in the Table 7 below. As seen from the table, most of the analyses were performed on the popular overtopping devices.

Table 7. Performance Analysis of Some Selected Overtopping Devices.

\begin{tabular}{|c|c|c|c|c|c|}
\hline ID & Name/Type & Scale & $\begin{array}{l}\text { Wave Energy } \\
\text { Potential }\end{array}$ & Efficiency & Comment \\
\hline 1 & $\begin{array}{l}\text { Sea Wave Slope } \\
\text { Cone Generator } \\
\text { (SSG) [147] }\end{array}$ & $\begin{array}{l}\text { Experimental } \\
(1 / 60) \text { of original }\end{array}$ & $19.5 \mathrm{~kW} / \mathrm{m}$ & $23 \%$ & $\begin{array}{c}{ }^{*} \text { Experiments modeled for } \\
\text { a field scale of } 10 \mathrm{~m} \\
\text { opening width }\end{array}$ \\
\hline 2 & Wavedragon [148] & $\begin{array}{l}\text { Sea trial and } \\
\text { simulation }\end{array}$ & $\begin{array}{l}* 6 \mathrm{~kW} / \mathrm{m} \\
* * 24 \mathrm{~kW} / \mathrm{m}\end{array}$ & $\begin{array}{l}\text { (a) } * 27 \% \\
\text { (b) } * * 18 \%\end{array}$ & $\begin{array}{l}{ }^{*} \text { width of device is } 65 \mathrm{~m} \\
* * \text { width of device is } 97 \mathrm{~m}\end{array}$ \\
\hline 3 & Bolgehovlen [149] & Prototype scale & $\begin{array}{c}16 \mathrm{~kW} / \mathrm{m} \\
* 16 \mathrm{~kW} / \mathrm{m} \\
* * 12 \mathrm{~kW} / \mathrm{m}\end{array}$ & $\begin{array}{c}8 \% \\
\text { (a) } * 23 \% \\
(\text { b) } \\
* * 26 \%\end{array}$ & $10 \mathrm{~m}$ width \\
\hline 4 & Wavedragon [98] & Prototype scale & $\begin{array}{l}* * * 21 \mathrm{~kW} / \mathrm{m} \\
* * * * 26 \mathrm{~kW} / \mathrm{m} \\
* * * * 15 \mathrm{~kW} / \mathrm{m}\end{array}$ & $\begin{array}{l}\text { (c) } * * * 23 \% \\
(d) * * * 21 \% \\
(\text { e) } * * * * 22 \%\end{array}$ & Width $300 \mathrm{~m}$ \\
\hline 5 & $\begin{array}{c}\text { Power } \\
\text { Pyramid [98] }\end{array}$ & & $16 \mathrm{~kW} / \mathrm{m}$ & $3 \%$ & $125 \mathrm{~m}$ width \\
\hline 6 & $\begin{array}{l}\text { Sucking Sea } \\
\text { Shaft [98] }\end{array}$ & & $16 \mathrm{~kW} / \mathrm{m}$ & $12 \%$ & $125 \mathrm{~m}$ width \\
\hline
\end{tabular}




\section{Comparing Power Efficiencies of Different Wave Energy Converter Types}

Unlike wind turbines in which increases in either the wind velocity or the swept area of the blades lead to an increase in the power capture, the interaction behavior between ocean waves and the WECs makes their power-absorbing characteristics different. Therefore, a more detailed analysis of WECs and sites properties needs to be undertaken before the design and deployment of these devices. The performance analysis of the WECs discussed in Sections 3-5 have shown that the reported efficiencies vary with the energy-capture technologies and site resource potential, as well as the characteristic width of the devices. Different attempts have been made to compare the performance of different WEC types. Notable among the work is the study performed by Babarit et al. [29]. They used numerical methods to determine the power output of four different types of heaving devices, two types of pitching devices, and a floating oscillating water column device. These devices were tested using data from five different test sites of well-defined wave energy resource assessment. The indices they used for the comparison include the annual mean absorbed power, the absorbed energy per surface area, the absorbed energy per characteristic mass, etc. Similar to Babarit's work is the one done by Rusu et al. [26], where numerical analysis was conducted with some very popular WEC devices in different regions of the world, and the performances were based on the harvested power versus the rated power of the devices. Other works include that the hydrodynamic efficiencies of different devices were tested in regions with same or similar wave energy resources [98]. Another equally important work was by Pecher [150]. This work introduced a frame work for estimating the performance of a WEC whether it is during wave tanks tests or open sea trials. While acknowledging the challenges and limitations such as wave energy potential and location in estimating the performance of WECs, a reasonable way to achieve this was described. For example, performance in wave tank tests can be based on sea states (performance curve), the non-dimensional surface, or by defining a scaling ratio to relate the tank tests to the prototype size. Finally, it was suggested that for comparing different types of WECs, economic indices may be used, or if it is the power performance, certain parameters should be taken into consideration as references such as the wave conditions, assessment procedures, conversion stage, reference width, scaling ratio, and the efficiency of the wave farm.

For the comparison analysis performed in the study, the focus will be on the hydrodynamic efficiencies of the devices. This is because it is the only stage of the conversion processes unique to ocean wave energy converters, and the major hindrance to the utilization of ocean wave energy is due to the low performance at this stage. Other conversion stages, such as the mechanical and electrical stages, are applicable to other types of power conversion systems.

Figure 3 shows the different efficiencies of the devices in relation to their characteristic widths. The oscillating bodies have the highest efficiencies with smaller sizes. It should be noted that these characteristic widths are just the part of the devices that is in contact with the ocean waves. The overtopping devices have larger characteristic widths because their arms are usually the part used in directing the ocean waves to the reservoir area. From Figure 4, the oscillating water columns and the oscillating body systems tend to perform better when the wave energy resource potentials increase, while that of overtopping devices seems to be constant irrespective of the amount of wave energy resource potential. This is expected since the amount of energy captured by overtopping devices depends on the wave height and the difference between the height of water storage and the turbine. In addition, the efficiencies recorded through simulations may tend to be higher than reality, as some of the losses may not be properly represented in a simulation. The same is applicable to efficiencies extrapolated from model tests to field-scaled devices. 


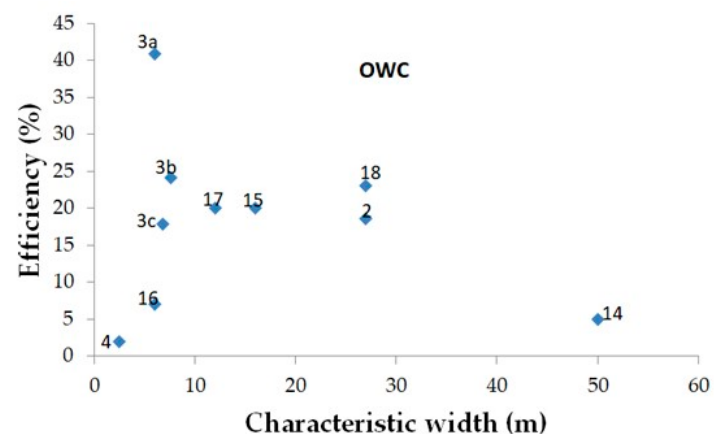

(a)

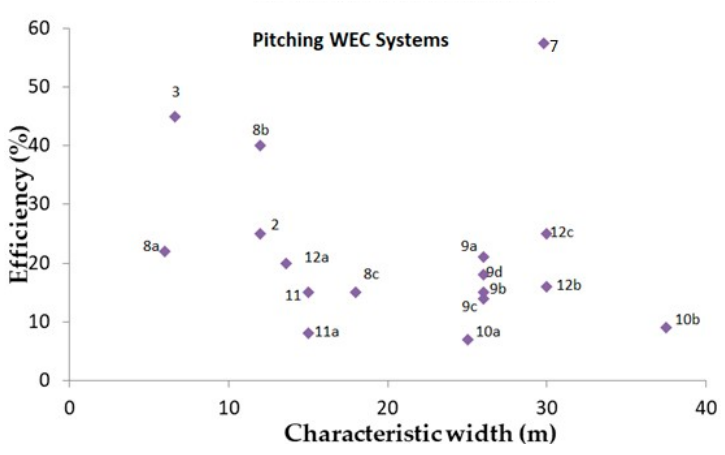

(c)

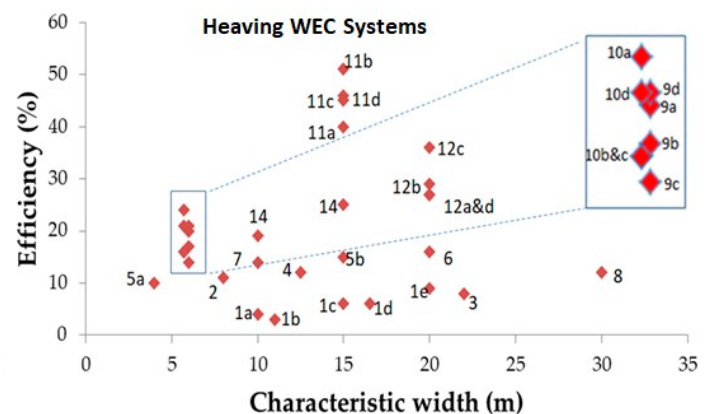

(b)

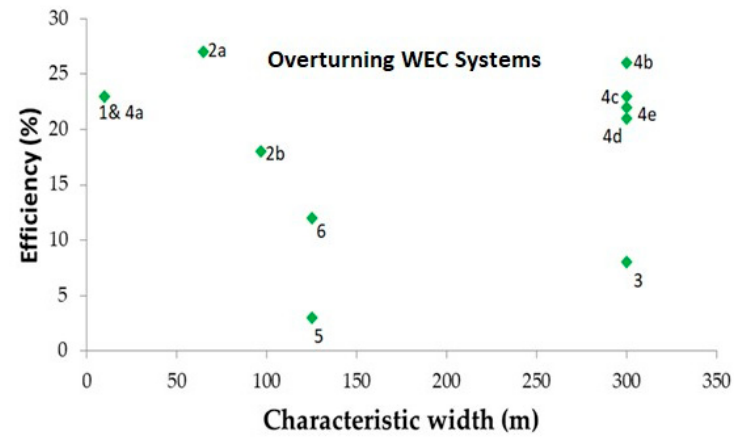

(d)

Figure 3. Efficiency of Wave Energy Converters versus their Characteristic Widths: (a) OWCs, (b) Heaving WECs, (c) Pitching WECs, and (d) Overtopping WECs.

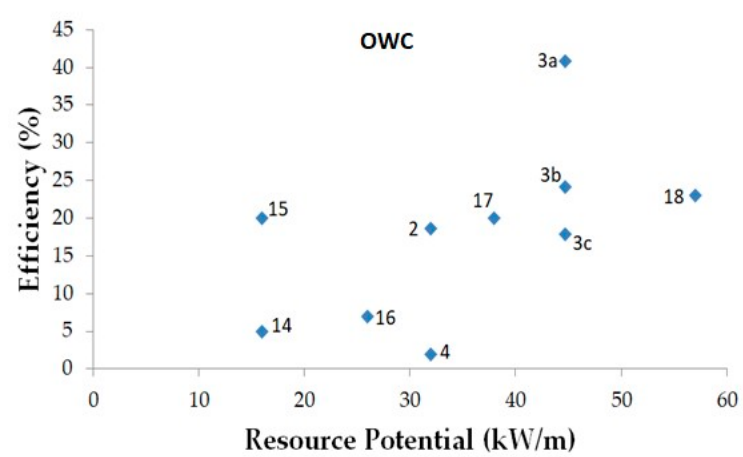

(a)

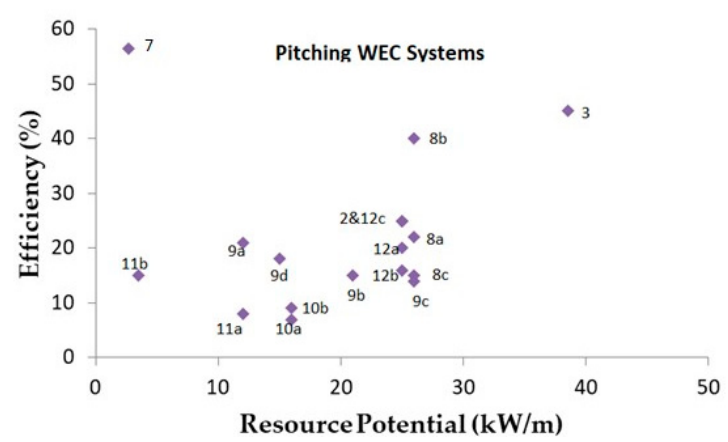

(c)

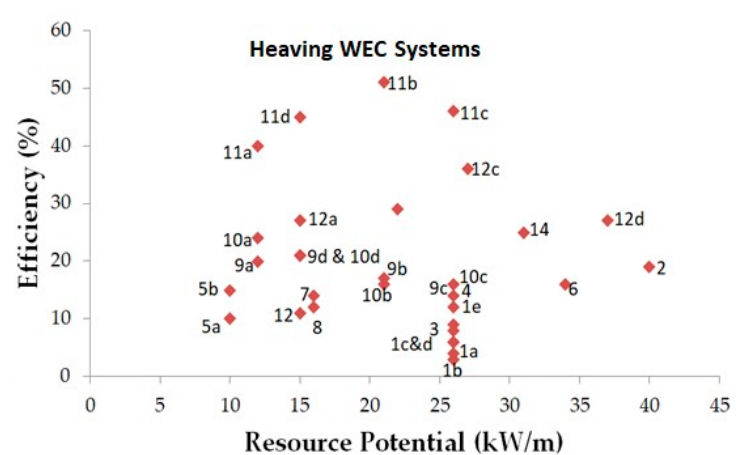

(b)

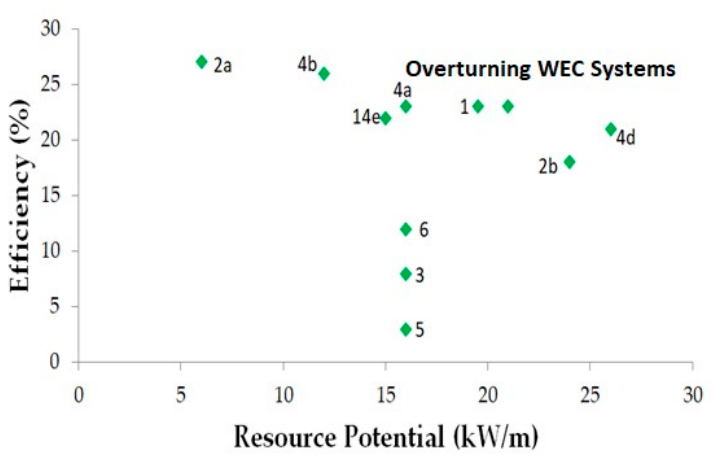

(d)

Figure 4. Efficiency of Wave Energy Converters versus Resource Potentials: (a) OWCs, (b) Heaving WECs, (c) Pitching WECs, and (d) Overtopping WECs. 


\section{Power Take-Off Systems}

The power take-off (PTO) of a WEC is an important part as it affects the overall performance of the WEC to deliver the desired electrical energy and the cost of the device. The overturning WECs, whose operation is similar to that of a small conventional hydroelectric power source, can use similar low head hydrokinetic turbines for their PTO systems. For oscillating body systems and oscillating water column systems, the main challenge is to convert the low velocity motion of the WEC to a unidirectional motion by the PTO system. Oscillating column systems use mostly air turbines for their PTO, while oscillating body systems' PTO can utilize any piston-like system, such as hydraulic drives, mechanical drives, or gas accumulators. In addition, direct drive linear generators can be also used for oscillating body converter systems because of their high efficiency. A comprehensive review on power take-off can be found in $[18,21]$. PTO systems used for wave energy converters are also used in other power-generating systems. Hence, their conversion efficiencies and capacities have been standardized by different manufacturers over the years. A typical conversion efficiency is given by [151] and summarized in Table 8 below.

Table 8. Typical PTO Efficiencies. PTO: power take-off.

\begin{tabular}{cc}
\hline PTO Type & Efficiency (\%) \\
\hline Hydraulic & 65 \\
Water & 85 \\
Air turbines & 55 \\
Mechanical drive & 90 \\
Direct drive linear generator & 95 \\
\hline
\end{tabular}

Similar with any other renewable energy systems, PTO systems that use WECs must be able to handle the intermittent nature of the power absorbed from the ocean wave by storing the energy temporarily so that the energy can be "smoothened" before transmission.

\section{Cost Trends of Wave Energy Converters}

Another important factor in evaluating wave energy converters' performance is the cost of energy produced. Prospective investors in the wave energy industry will only be interested if there will be a reasonable return on their investments. Therefore, ocean wave energy harvesting needs to not only be profitable, it also needs to be competitive, as it is not the only renewable energy resource available offshore. So, beyond the increase in power production of WECs from the current production rate, there is a need to simultaneously reduce the cost of power production and increase the reliability of the whole system. Since ocean wave energy is at the infancy of the commercialization stage, very few studies exist in which robust costs and economic analysis have been analyzed. The studies available are project specific and study the factors influencing the cost, such as construction and installation costs, operation and maintenance costs, tariff rates, insurance, etc.

A comprehensive study was carried out by [152] on the Pelamis device based on a location with a well-characterized resource in Ireland. Sensitivity analysis was performed on factors such as capital expenses, operating expense, insurance cost, capacity, and scale of wave energy farm to see how they influence the cost of power produced. At the time of the study, the project may not be viable economically based on the electricity pricing regime that was presented in Ireland. Other early studies related to the cost of power produced from ocean waves included the one sponsored by the United States Department of Interior [153], which predicted that the cost of power production from a hypothetical wave farm of 90-MW capacity will reduce from about $\$ 2600 / \mathrm{kW}$ in $2008-2011$ to $\$ 1325 / \mathrm{kW}$ in 2024-2027. The work by [154] estimated the costs of energy generation between $\$ 1960 / \mathrm{kW}$ and $\$ 4900 / \mathrm{kW}$ in the United Kingdom. The performance of the Pelamis was also studied in California, USA [155]. After analyzing the wave energy resource present in the region, it was estimated that the cost of power generation would be $\$ 7500 / \mathrm{kW}$ and $\$ 2600 / \mathrm{kW}$ for a wave energy farm of $1 \mathrm{MW}$ 
and $105 \mathrm{MW}$ capacity, respectively, based on the 2004 dollar value. At this cost of power production, the levelized cost of energy is about 11.2 cents per $\mathrm{kWh}$, while the cost of energy for onshore wind energy was 3 cents/kWh at the same time. The cost of ocean wave energy in a 100-MW farm with a capacity factor of $33 \%$ was compared with other sources of renewable and conventional energy in Scotland. The energy generated by the wave energy converter system remained the highest, which is more than double the closest to it, including tidal and offshore wind. However, the cost is also about four times higher than sources such as nuclear and coal [156]. A more comprehensive work [157] was performed to determine the cost of energy produced in the UK, Spain, USA, France, Canada, and Chile. Costs, involving the structural cost, installation, mooring, etc., were compared for a multipoint absorber and a multibody pitching device. The resource capacity of the areas tested ranged from $5.8 \mathrm{~kW} / \mathrm{m}$ to $28.5 \mathrm{~kW} / \mathrm{m}$. The levelized cost of energy was lowest in the USA with about $\$ 0.84 / \mathrm{kWh}$ and highest in France, which costs $\$ 1.6 / \mathrm{kWh}$. Apart from Canada and France, which show a high difference between the cost for multipoint absorber systems and multibody pitching devices, there is very little difference between the two types of devices in other locations. A specific study on an overtopping converter tested in nine different locations with wave energy resources ranging from $42 \mathrm{~kW} / \mathrm{m}$ to $62 \mathrm{~kW} / \mathrm{m}$ [158]. The payback period ranged from about 10 months to 50 months at different locations. New studies have emerged to obtain a framework to estimate the economics and cost involved irrespective of the type of WECs. The analysis involved determining the power matrix of the converter type with respect to the available wave energy resource in the area. Other factors include costs related to construction and installation, maintenance cost, etc. [159-161]. In addition, some recent research studies $[162,163]$ have studied the possibility of the collocation of wave energy converters and offshore wind turbines at the same geographical area to increase the energy output and reduce the variability of energy output, which also creates a number of important synergies and advantages including a reduction of installation costs combining foundations, electrical infrastructure, installation, planning and development, and a reduction of operational and maintenance costs.

\section{Conclusions}

This paper has tracked the power performance of different types of wave energy converters over the years. The converters were classified according to the types of harvesting technology, which are oscillating water columns, oscillating body systems, and overtopping devices. The reported efficiencies of different wave energy converters from different studies were identified to as the whether the analyses were based on numerical and simulation methods, laboratory experiments in wave tanks, field tests in open sea conditions, or a combination of two or more methods. Most of the studies considered in this paper are based on numerical and simulation analyses with few progressing to field tests. Very few go on to be connected to an electric grid. Most of the efficiencies reported in numerical simulations and laboratory experiments are higher than those of the open-field tests.

In order to compare the performance and efficiencies of the wave energy converters analyzed in this paper, the efficiencies at different stages of power conversion were identified in order to not confuse the different efficiencies reported in different studies. The efficiencies at these conversion stages are separated into pneumatic/hydrodynamic efficiency, turbine/mechanical efficiency, electrical efficiency, and transmission efficiency. However, the hydrodynamic efficiency is used to compare different WECs with different capture technologies. This is because this stage of conversion is the only one unique to the ocean wave energy system. The hydrodynamic efficiency in relation to the characteristic width of the converters and the wave energy resource potential at testing locations were determined and compared. The result showed that the oscillating body systems performed the best, while the overtopping devices performed the worst based on the characteristic width of the devices. Meanwhile, as ocean wave power is primarily decided by two ocean properties (wave height and wave period), the oscillating water column and oscillating body systems tend to increase in performance as the wave energy resource potential increases. 
The costs of the production of power from the wave energy converters are also discussed. As expected, the levelized cost of energy reduces as the capacity of the wave farm increases. However, the costs will also be determined by other factors such as the water depth. Water depth will definitely affect fixed structures compared to floating structures. The transmission cost will increase if the distance at which the WECs are further offshore increases. The transmission cost can be reduced through the sharing of facilities installed, such as an offshore wind turbine if it is available. The costs will further reduce and make ocean wave energy competitive with other energy sources as technology improves, incrementally increasing the power production per unit device, the use of cost effective material, etc. Very few studies have shown that investment in ocean wave energy can currently return a decent profit where there is very little or no alternative form of power source.

It should be noted that the various efficiencies reported in this study are related to the ratio of the power absorbed by the WEC to the available power in the ocean wave front before transferring to the PTO system. Therefore, there are still many stages of the power conversion process to be considered before the 'best' design or type of WEC can be chosen. Meanwhile, the efficiency of a WEC depends on the device's scale, type, and ocean wave resource assessment. Therefore, choosing the desired design of a WEC will be tailored to the objective of the designer, which could be the overall power performance, cost of energy production, survivability, environmental concerns, etc.

Tracking the power and economic performance of wave energy converters will enable the monitoring of the growth of the ocean wave energy industry. For the utilization of ocean wave energy to reach the commercial stage as wind and solar energy have, the amount of energy absorbed primarily from the ocean wave, which is the hydrodynamic conversion stage, must be substantial. It should be noted that the efficiencies reported in this paper are based on the annual average. Further studies investigating the time variation of the power-absorbing efficiency and methods in which to condition this power to be acceptable on the electricity grid will go a long way in assessing WECs' performance. After a comprehensive understanding of the power and associated cost capture is achieved, analyses investigating the commercial and environmental feasibilities can also be conducted in the future.

Author Contributions: T.A. wrote the initial draft paper under the supervision of H.L. H.L. made major revisions on the initial draft paper, and approved the final version to be published.

Acknowledgments: The authors are thankful to the support from the Texas A\&M University-Kingsville and National Science Foundation (award \# EEC-1757812).

Conflicts of Interest: The authors declare no conflict of interest. The funding sponsors had no role in the design of the study; in the collection, analyses, or interpretation of data; in the writing of the manuscript; or in the decision to publish the results.

\section{References}

1. Mork, G.; Barstow, S.; Kabuth, A.; Pontes, M.T. Assessing the global wave energy potential. In Proceedings of the ASME 2010 29th International Conference on Ocean, Offshore and Arctic Engineering, Shanghai, China, 6-11 June 2010; pp. 447-454.

2. Izadparast, A.H.; Niedzwecki, J.M. Estimating the potential of ocean wave power resources. Ocean Eng. 2011, 38, 177-185. [CrossRef]

3. Mollison, D. Wave climate and the wave power resource. In Hydrodynamics of Ocean Wave-Energy Utilization; Springer: Berlin/Heidelberg, Germany, 1986; pp. 133-156.

4. Lenee-Bluhm, P.; Paasch, R.; Özkan-Haller, H.T. Characterizing the wave energy resource of the US Pacific Northwest. Renew. Energy 2011, 36, 2106-2119. [CrossRef]

5. Iglesias, G.; López, M.; Carballo, R.; Castro, A.; Fraguela, J.A.; Frigaard, P. Wave energy potential in Galicia (NW Spain). Renew. Energy 2009, 34, 2323-2333. [CrossRef]

6. Citiroglu, H.K.; Okur, A. An approach to wave energy converter applications in Eregli on the western Black Sea coast of Turkey. Appl. Energy 2014, 135, 738-747. [CrossRef]

7. Haces-Fernandez, F. Investigation on the Possibility of Extracting Wave Energy from the Texas Coast. Master's Thesis, Texas A\&M University, Kingsville, TX, USA, 2014. 
8. Ocean Energy Systems. Annual Report Ocean Energy Systems 2016. 2017. Available online: https: //report2016.ocean-energy-systems.org/ (accessed on 11 March 2018).

9. Jacobson, P.T.; Hagerman, G.; Scott, G. Mapping and Assessment of the United States Ocean Wave Energy Resource; No. DOE/GO/18173-1; Electric Power Research Institute: Palo Alto, CA, USA, 2011.

10. Lawrence, J.; Kofoed-Hansen, H.; Chevalier, C. High-resolution metocean modelling at EMEC's (UK) marine energy test sites. In Proceedings of the 8th European Wave and Tidal Energy Conference, Uppsala, Sweden, 7-10 September 2009; pp. 7-10.

11. Neary, V.S.; Lawson, M.; Previsic, M.; Copping, A.; Hallett, K.C.; LaBonte, A.; Murray, D. Methodology for Design and Economic Analysis of Marine Energy Conversion (MEC) Technologies; No. SAND2014-3561C; Sandia National Lab. (SNL-NM): Albuquerque, NM, USA, 2014.

12. Cada, G.; Ahlgrimm, J.; Bahleda, M.; Bigford, T.; Stavrakas, S.D.; Hall, D.; Sale, M. Potential impacts of hydrokinetic and wave energy conversion technologies on aquatic environments. Fisheries 2007, 32, 174-181. [CrossRef]

13. Available online: https://www.oceanpowertechnologies.com/ (accessed on 14 November 2018).

14. Brekken, T.K.; Von Jouanne, A.; Han, H.Y. Ocean wave energy overview and research at Oregon State University. In Proceedings of the Power Electronics and Machines in Wind Applications, Lincoln, NE, USA, 24-26 June 2009; pp. 1-7.

15. Whittaker, T.; Collier, D.; Folley, M.; Osterried, M.; Henry, A.; Crowley, M. The development of Oyster-A shallow water surging wave energy converter. In Proceedings of the 7th European Wave and Tidal Energy Conference, Porto, Portugal, 1 September 2007; pp. 11-14.

16. Available online: https://www.energy.gov/eere/water/about (accessed on 19 October 2018).

17. Pelc, R.; Fujita, R.M. Renewable energy from the ocean. Mar. Policy 2002, 26, 471-479. [CrossRef]

18. Aderinto, T.; Li, H. Ocean Wave Energy Converters: Status and Challenges. Energies 2018, 11, 1250. [CrossRef]

19. Lehmann, M.; Karimpour, F.; Goudey, C.A.; Jacobson, P.T.; Alam, M.R. Ocean wave energy in the United States: Current status and future perspectives. Renew. Sustain. Energy Rev. 2017, 74, 1300-1313. [CrossRef]

20. Clément, A.; McCullen, P.; Falcão, A.; Fiorentino, A.; Gardner, F.; Hammarlund, K.; Pontes, M.T. Wave energy in Europe: Current status and perspectives. Renew. Sustain. Energy Rev. 2002, 6, 405-431. [CrossRef]

21. Falcao, A.D.O. Wave energy utilization: A review of the technologies. Renew. Sustain. Energy Rev. 2010, 14, 899-918. [CrossRef]

22. Whittaker, T.J.T.; McIlwaine, S.J.; Raghunathan, S. A review of the Islay shoreline wave power station. In Proceedings of the European Wave Energy Symposium, Edinburgh, Scotland, 21-24 July 1993; pp. 283-286.

23. Ohneda, H.; Igarashi, S.; Shinbo, O.; Sekihara, S.; Suzuki, K.; Kubota, H.; Morita, H. Construction procedure of a wave power extracting caisson breakwater. In Proceedings of the 3rd Symposium on Ocean Energy Utilization, Tokyo, Japan, 22-23 January 1991; pp. 171-179.

24. Ravindran, M.; Koola, P.M. Energy from sea waves-The Indian wave energy programme. Curr. Sci. 1991, 60, 676-680.

25. Rusu, E.; Onea, F. Estimation of the wave energy conversion efficiency in the Atlantic Ocean close to the European islands. Renew. Energy 2016, 85, 687-703. [CrossRef]

26. Rusu, L.; Onea, F. The performance of some state-of-the-art wave energy converters in locations with the worldwide highest wave power. Renew. Sustain. Energy Rev. 2017, 75, 1348-1362. [CrossRef]

27. Babarit, A.; Hals, J.; Muliawan, M.J.; Kurniawan, A.; Moan, T.; Krokstad, J. Numerical benchmarking study of a selection of wave energy converters. Renew. Energy 2012, 41, 44-63. [CrossRef]

28. Babarit, A. A database of capture width ratio of wave energy converters. Renew. Energy 2015, 80, 610-628. [CrossRef]

29. Astariz, S.; Iglesias, G. The economics of wave energy: A review. Renew. Sustain. Energy Rev. 2015, 45, 397-408. [CrossRef]

30. Hughes, S. Physical Models and Laboratory Techniques in Coastal Engineering; World Scientific: Singapore, 1993; p. 7.

31. Aderinto, T.O.; Haces-Fernandez, F.; Li, H. Design and Potential Application of Small Scale Wave Energy Converter. In Proceedings of the ASME 2017 International Mechanical Engineering Congress and Exposition, Tampa, FL, USA, 3-9 November 2017; p. V006T08A084. [CrossRef]

32. Evans, D.V. A theory for wave-power absorption by oscillating bodies. J. Fluid Mech. 1976, 77, 1-25. [CrossRef] 
33. Budar, K.; Falnes, J. A resonant point absorber of ocean-wave power. Nature 1975, 256, 478-479. [CrossRef]

34. Mei, C.C. Power extraction from water waves. J. Ship Res. 1976, 20, 63-66.

35. Falnes, J. Optimum Control of Oscillation of Wave-Energy Converters. In Proceedings of the Eleventh International Offshore and Polar Engineering Conference, Stavanger, Norway, 17-22 June 2002.

36. Davidson Laboratory of Stevens Institute of Technology. Available online: http://www.stevens.edu/ses/ davidson/facilities/design-evaluation (accessed on 19 November 2018).

37. DeFrees Hydraulics Lab. Available online: http://www.cee.cornell.edu/about/facilities/defrees.cfm (accessed on 15 November 2018).

38. Fluid Mechanics Laboratory at Clemson University. Available online: http://www.clemson.edu/ces/coastal/ facilities.html (accessed on 20 November 2018).

39. Haynes Coastal Engineering Laboratory. Available online: http://coastal.tamu.edu/forindustry.html (accessed on 19 November 2018).

40. Available online: https://marineenergy.biz/2015/05/29/china-to-advance-wave-energy-with-three-test-sites/ (accessed on 19 November 2018).

41. Wang, L.; Isberg, J.; Tedeschi, E. Review of control strategies for wave energy conversion systems and their validation: The wave-to-wire approach. Renew. Sustain. Energy Rev. 2018, 81, 366-379. [CrossRef]

42. Available online: http://www.danwec.com/ (accessed on 19 November 2018).

43. Available online: https://www.wavehub.co.uk/ (accessed on 19 November 2018).

44. Available online: http://www.semrev.fr/en/ (accessed on 19 November 2018).

45. Available online: https://tethys.pnnl.gov/annex-iv-sites/atlantic-marine-energy-test-site-amets (accessed on 19 November 2018).

46. Available online: http://www.seai.ie/Renewables/Ocean_Energy/Belmullet_Wave_Energy_Test_Site/ (accessed on 19 November 2018).

47. Available online: http://www.rundecentre.no/ (accessed on 19 November 2018).

48. Palha, A.; Mendes, L.; Fortes, C.J.; Brito-Melo, A.; Sarmento, A. The impact of wave energy farms in the shoreline wave climate: Portuguese pilot zone case study using Pelamis energy wave devices. Renew. Energy 2010, 35, 62-77. [CrossRef]

49. Available online: http://www.emec.org.uk/ (accessed on 19 November 2018).

50. Available online: http://www.eve.es/energia_marina/index_cas.htm (accessed on 19 November 2018).

51. Available online: http://www.plocan.eu/es/ (accessed on 19 November 2018).

52. Available online: http://www.folkecenter.net/gb/rd/wave-energy/ (accessed on 19 November 2018).

53. Available online: http://www.marine.ie/home/aboutus/organisationstaff/researchfacilities/Ocean+Energy+ Test+Site.htm (accessed on 19 November 2018).

54. Available online: http://www.fabtest.com/ (accessed on 19 November 2018).

55. Available online: http://pacwaveenergy.org/ (accessed on 19 November 2018).

56. Batten, B.; Hellin, D. The Pacific Marine Energy Center-South Energy Test Site (PMEC-SETS); (No. DOE_PMECSETS_-02072018); Oregon State Univ.: Corvallis, OR, USA, 2018.

57. Available online: https://www.hnei.hawaii.edu/projects/wave-energy-test-site-wets (accessed on 20 November 2018).

58. Ni, C. Development of Ocean Energy Test Field in China. J. Shipp. Ocean Eng. 2015, 5, 44-49.

59. Masuda, Y. Wave-Activated Generator. U.S. Patent 4,539,485, 3 September 1985.

60. Masuda, Y.; McCormick, M.E. Experiences in pneumatic wave energy conversion in Japan. In Utilization of Ocean Waves-Wave to Energy Conversion; ASCE: Reston, VA, USA, 1986; pp. 1-33.

61. Bønke, K.; Ambli, N. Prototype wave power stations in Norway. In Utilization of Ocean Waves-Wave to Energy Conversion; ASCE: Reston, VA, USA, 1986; pp. 34-45.

62. Malmo, O.; Reitan, A. Wave-power absorption by an oscillating water column in a channel. J. Fluid Mech. 1985, 158, 153-175. [CrossRef]

63. Heath, T.; Whittaker, T.J.T.; Boake, C.B. The design, construction and operation of the LIMPET wave energy converter (Islay, Scotland). In Proceedings of the 4th European Wave Energy Conference, Aalborg, Denmark, 4 December 2000; pp. 49-55.

64. Boake, C.B.; Whittaker, T.J.; Folley, M.; Ellen, H. Overview and initial operational experience of the LIMPET wave energy plant. In Proceedings of the Twelfth International Offshore and Polar Engineering Conference, Kitakyushu, Japan, 26-31 May 2002. 
65. Available online: http://www.yentha.com/news/view/4/innovation-lost-to-the-waves (accessed on 12 November 2018).

66. Falcao, A.D.O. The shoreline OWC wave power plant at the Azores. In Proceedings of the Fourth European Wave Energy Conference, Aalborg, Denmark, 4 December 2000; pp. 4-6.

67. Available online: http://www.pico-owc.net/ (accessed on 15 November 2018).

68. Vieira, M.; Monk, K.; Sarmento, A.; Reis, L. The Pico power plant as an infrastructure for development, research and graduation. In Congresso de Ciência e Desenvolvimento dos Açores; ACDA: Angra do Heroísmo, Portugal, 2013.

69. Le Crom, I.; Brito-Melo, A.; Neumann, F.; Sarmento, A.J.N.A. Portuguese grid connected OWC power plant: Monitoring Report. In Proceedings of the Twentieth International Offshore and Polar Engineering Conference, Beijing, China, 20-25 June 2010.

70. Alcorn, R.; Hunter, S.C.O.T.T.; Signorelli, C.; Obeyesekera, R.A.N.J.I.; Finnigan, T.; Denniss, T. Results of the Testing of the Energetech Wave Energy Plant at Port Kembla 26 October 2005 Tech. Rep.; Energetech Australia Pty Limited: Kensington, Australia, 2005.

71. Lindroth, S.; Leijon, M. Offshore wave power measurements-A review. Renew. Sustain. Energy Rev. 2011, 15, 4274-4285. [CrossRef]

72. Torre-Enciso, Y.; Ortubia, I.; de Aguileta, L.L.; Marqués, J. Mutriku wave power plant: From the thinking out to the reality. In Proceedings of the 8th European Wave and Tidal Energy Conference, Uppsala, Sweden, 7-10 September 2009; Volume 710, p. 319329.

73. Available online: https://www.power-technology.com/projects/mutriku-wave/ (accessed on 19 November 2018).

74. Washio, Y.; Osawa, H.; Nagata, Y.; Fujii, F.; Furuyama, H.; Fujita, T. The offshore floating type wave power device "Mighty Whale": Open sea tests. In Proceedings of the Tenth International Offshore and Polar Engineering Conference, Seattle, WA, USA, 28 May-2 June 2000.

75. OES Annual Report 2014. REPUBLIC OF KOREA. Technology Demonstration. Available online: https://report2014.ocean-energy-systems.org/countryreports/republic-of-korea/technology-demonstration/ (accessed on 14 November 2018).

76. Brito-Melo, A.; Hofmann, T.; Sarmento, A.J.N.A.; Clément, A.H.; Delhommeau, G. Numerical modelling of OWC-shoreline devices including the effect of surrounding coastline and non-flat bottom. Int. J. Offshore Polar Eng. 2001, 11, 2.

77. Brito-Melo, A.; Gato, L.M.C.; Sarmento, A.J.N.A. Analysis of Wells turbine design parameters by numerical simulation of the OWC performance. Ocean Eng. 2002, 29, 1463-1477. [CrossRef]

78. Hotta, H.; Washio, Y.; Yokozawa, H.; Miyazaki, T. R\&D on wave power device "Mighty Whale". Renew. Energy 1996, 9, 1223-1226.

79. Sarmento, A.J.; e Melo, A.B.; Pontes, M.T. The influence of the wave climate on the design and annual production of electricity by OWC wave power plants. J. Offshore Mech. Arct. Eng. 2003, 125, 139-144. [CrossRef]

80. Masuda, Y.; Xianguang, L.; Xiangfan, G. High performance of cylinder float backward bent duct buoy (BBDB) and its use in European seas. In Proceedings of the (First) European Wave Energy Symposium, Edinburgh, UK, 30 October-1 November 1993; pp. 323-337.

81. Mamun, M.A.H.; Nagata, S.; Toyota, K.; Imai, Y.; Setoguchi, T. Numerical Simulation of Backward Bent Duct Buoy by Moving Particle Semi-implicit Method. In Proceedings of the 13th Asian Congress of Fluid Mechanics, Duaka, Bangladesh, 17-21 December 2010.

82. Lee, K.R.; Koo, W.; Kim, M.H. Fully nonlinear time-domain simulation of a backward bent duct buoy floating wave energy converter using an acceleration potential method. Int. J. Nav. Archit. Ocean Eng. 2013, 5, 513-528. [CrossRef]

83. Bailey, H.; Robertson, B.R.; Buckham, B.J. Wave-to-wire simulation of a floating oscillating water column wave energy converter. Ocean Eng. 2016, 125, 248-260. [CrossRef]

84. Maldonado Rivera, C.I. Stochastic modelling of OWC device and power production. Master's. Thesis, Pontificia Universidad Catolica De Chile Escuela De Ingenieria, Santiago, Chile, 2017.

85. Henriques, J.C.C.; Portillo, J.C.C.; Gato, L.M.C.; Gomes, R.P.F.; Ferreira, D.N.; Falcão, A.F.O. Design of oscillating-water-column wave energy converters with an application to self-powered sensor buoys. Energy 2016, 112, 852-867. [CrossRef] 
86. Falcao, A.D.O.; Rodrigues, R.J.A. Stochastic modelling of OWC wave power plant performance. Appl. Ocean Res. 2002, 24, 59-71. [CrossRef]

87. Falcao, A.D.O. Stochastic modelling in wave power-equipment optimization: Maximum energy production versus maximum profit. Ocean Eng. 2004, 31, 1407-1421. [CrossRef]

88. Falcao, A.D.O.; Justino, P.A.P. OWC wave energy devices with air flow control. Ocean Eng. 1999, 26, 1275-1295. [CrossRef]

89. Ning, D.Z.; Wang, R.Q.; Zou, Q.P.; Teng, B. An experimental investigation of hydrodynamics of a fixed OWC Wave Energy Converter. Appl. Energy 2016, 168, 636-648. [CrossRef]

90. Iino, M.; Miyazaki, T.; Segawa, H.; Iida, M. Effect of inclination on oscillation characteristics of an oscillating water column wave energy converter. Ocean Eng. 2016, 116, 226-235. [CrossRef]

91. Ashlin, S.J.; Sundar, V.; Sannasiraj, S.A. Effects of bottom profile of an oscillating water column device on its hydrodynamic characteristics. Renew. Energy 2016, 96, 341-353. [CrossRef]

92. E Silva, S.R.; Gomes, R.P.F.; Falcão, A.F.O. Hydrodynamic optimization of the UGEN: Wave energy converter with U-shaped interior oscillating water column. Int. J. Mar. Energy 2016, 15, 112-126. [CrossRef]

93. Henriques, J.C.C.; Gato, L.M.C.; Lemos, J.M.; Gomes, R.P.F.; Falcão, A.F.O. Peak-power control of a grid-integrated oscillating water column wave energy converter. Energy 2016, 109, 378-390. [CrossRef]

94. Strati, F.M.; Malara, G.; Arena, F. Performance optimization of a U-Oscillating-Water-Column wave energy harvester. Renew. Energy 2016, 99, 1019-1028. [CrossRef]

95. Henriques, J.C.C.; Gomes, R.P.F.; Gato, L.M.C.; Falcão, A.F.O.; Robles, E.; Ceballos, S. Testing and control of a power take-off system for an oscillating-water-column wave energy converter. Renew. Energy 2016, 85, 714-724. [CrossRef]

96. Ceballos, S.; Rea, J.; Lopez, I.; Pou, J.; Robles, E.; O'Sullivan, D.L. Efficiency optimization in low inertia wells turbine-oscillating water column devices. IEEE Trans. Energy Convers. 2013, 28, 553-564. [CrossRef]

97. Ceballos, S.; Rea, J.; Robles, E.; Lopez, I.; Pou, J.; O'Sullivan, D. Control strategies for combining local energy storage with wells turbine oscillating water column devices. Renew. Energy 2015, 83, 1097-1109. [CrossRef]

98. Meyer, N.I.; Arnskov, M.M.; Bennetzen, L.V.; Burcharth, H.F.; Bunger, J.; Jacobsen, V.; Sørensen, J.N. Bølgekraftprogram: Afsluttende rapport fra Energistyrelsens Rådgivende Bølgekraftudvalg. Bølgekraftudvalgets Sekr. Rambøll Tek. 2002, 31, 2830.

99. Pecher, A.; Kofoed, J.P.; Le Crom, I.; Neumann, F.; Azevedo, E.D.B. Performance assessment of the Pico OWC power plant following the EquiMar methodology. In Proceedings of the Twenty-First International Offshore and Polar Engineering Conference, Hawaii, HI, USA, 19-24 June 2011.

100. Rendel Palmer \& Tritton and Kennedy \& Donkin. “United Kingdom Wave Energy Program-Consultants' 1981 Assessment", Department of Energy. 1982. Available online: http:/www.homepages.ed.ac.uk/shs/ MIT\%20visit/9_Official\%20Consultant\%20Assessment\%201981.pdf (accessed on 12 November 2019).

101. Valério, D.; Beirão, P.; da Costa, J.S. Optimisation of wave energy extraction with the Archimedes Wave Swing. Ocean Eng. 2007, 34, 2330-2344. [CrossRef]

102. Yeung, R.W.; Jiang, Y. Shape effects on viscous damping and motion of heaving cylinders. J. Offshore Mech. Arct. Eng. 2014, 136, 041801. [CrossRef]

103. Ferri, F.; Ambühl, S.; Fischer, B.; Kofoed, J.P. Balancing power output and structural fatigue of wave energy converters by means of control strategies. Energies 2014, 7, 2246-2273. [CrossRef]

104. Sergiienko, N.Y.; Cazzolato, B.S.; Ding, B.; Hardy, P.; Arjomandi, M. Performance comparison of the floating and fully submerged quasi-point absorber wave energy converters. Renew. Energy 2017, 108, 425-437. [CrossRef]

105. Feng, Z.; Kerrigan, E.C. Latching control of wave energy converters using derivative-free optimization. In Proceedings of the 52nd IEEE Conference on Decision and Control, Florence, Italy, 10-13 December 2013.

106. Wu, J.; Yao, Y.; Zhou, L.; Göteman, M. Latching and Declutching Control of the Solo Duck Wave-Energy Converter with Different Load Types. Energies 2017, 10, 2070. [CrossRef]

107. Budal, K.; Falnes, J. Interacting Point Absorbers with Controlled Motion. Power from Sea Waves; Academic Press: London, UK, 1980; pp. 381-399.

108. Salter, S.H.; Taylor, J.R.M.; Caldwell, N.J. Power conversion mechanisms for wave energy. Proc. Inst. Mech. Eng. Part M J. Eng. Marit. Environ. 2002, 216, 1-27. [CrossRef]

109. Babarit, A.; Duclos, G.; Clément, A.H. Comparison of latching control strategies for a heaving wave energy device in random sea. Appl. Ocean Res. 2004, 26, 227-238. [CrossRef] 
110. Falcao, A.D.O. Phase control through load control of oscillating-body wave energy converters with hydraulic PTO system. Ocean Eng. 2008, 35, 358-366. [CrossRef]

111. Korde, U.A. Latching control of deep water wave energy devices using an active reference. Ocean Eng. 2002, 29, 1343-1355. [CrossRef]

112. Thomas, G.P.; Evans, D.V. Arrays of three-dimensional wave-energy absorbers. J. Fluid Mech. 1981, 108, 67-88. [CrossRef]

113. Shadman, M.; Estefen, S.F.; Rodriguez, C.A.; Nogueira, I.C. A geometrical optimization method applied to a heaving point absorber wave energy converter. Renew. Energy 2018, 115, 533-546. [CrossRef]

114. Goggins, J.; Finnegan, W. Shape optimisation of floating wave energy converters for a specified wave energy spectrum. Renew. Energy 2014, 71, 208-220. [CrossRef]

115. Flocard, F.; Finnigan, T.D. Increasing power capture of a wave energy device by inertia adjustment. Appl. Ocean Res. 2012, 34, 126-134. [CrossRef]

116. Esmaeilzadeh, S.; Alam, M.R. Shape Optimization of Wave Energy Converters for Broadband Directional Incident Waves. arXiv 2018, arXiv:1805.08294. [CrossRef]

117. Bachynski, E.E.; Young, Y.L.; Yeung, R.W. Analysis and optimization of a tethered wave energy converter in irregular waves. Renew. Energy 2012, 48, 133-145. [CrossRef]

118. Sjökvist, L.; Krishna, R.; Rahm, M.; Castellucci, V.; Anders, H.; Leijon, M. On the optimization of point absorber buoys. J. Mar. Sci. Eng. 2014, 2, 477-492. [CrossRef]

119. Hirohisa, T. Sea trial of a heaving buoy wave power absorber. In Proceedings of the 2nd International Symposium on Wave Energy Utilization, Trondheim, Norway, 22-24 June 1982; pp. 403-417.

120. Budal, K.; Falnes, J.; Iversen, L.C.; Lillebekken, P.M.; Oltedal, G.; Hals, T.; Høy, A.S. The Norwegian Wave-Power Buoy Project. 1982. Available online: http://hdl.handle.net/11250/246709 (accessed on 11 November 2019).

121. Falnes, J. Wave-energy conversion through relative motion between two single-mode oscillating bodies. J. Offshore Mech. Arct. Eng. 1999, 121, 32-38. [CrossRef]

122. Beatty, S.J.; Buckham, B.J.; Wild, P. Frequency response tuning for a two-body heaving wave energy converter. In Proceedings of the Eighteenth International Offshore and Polar Engineering Conference, Vancouver, BC, Canada, 6-11 June 2008.

123. Available online: https://www.oceanpowertechnologies.com/powerbuoy (accessed on 19 November 2018).

124. Baudry, V.; Babarit, A. Assessment of the annual energy production of a heaving wave energy converter sliding on the mast of a fixed offshore wind turbine. In Proceedings of the Renewable Energy Congress XI (WREC XI), Abu Dhabi, UAE, 25-30 September 2010.

125. Oskamp, J.A.; Özkan-Haller, H.T. Power calculations for a passively tuned point absorber wave energy converter on the Oregon coast. Renew. Energy 2012, 45, 72-77. [CrossRef]

126. Zanuttigh, B.; Angelelli, E.; Kofoed, J.P. Effects of mooring systems on the performance of a wave activated body energy converter. Renew. Energy 2013, 57, 422-431. [CrossRef]

127. Sjolte, J.; Bjerke, I.; Tjensvoll, G.; Molinas, M. Summary of performance after one year of operation with the Lifesaver Wave Energy Converter System. In Proceedings of the 10th European Wave and Tidal Energy Conference, Aalborg, Denmark, 2-5 September 2013.

128. De Andrés, A.D.; Guanche, R.; Vidal, C.; Losada, Í.J. Analysis of the geometric tunability of a WEC from a worldwide perspective. In Proceedings of the ASME 2014 33rd International Conference on Ocean, Offshore and Arctic Engineering, San Francisco, CA, USA, 8-13 June 2014; p. V09AT09A039.

129. Previsic, M.; Bedard, R.; Hagerman, G. E2I EPRI Assessment, Offshore Wave Energy Conversion Devices; Technical Report E2I EPRI WP-004-US-Rev 1; Electricity Innovation Institute: PALO ALTO, CA, USA, 2002.

130. Kamizuru, Y. Development of Hydrostatic Drive Trains for Wave Energy Converters; Shaker: Herzogenrath, Germany, 2014.

131. Pecher, A.; Kofoed, J.P.; Larsen, T.; Marchalot, T. Experimental study of the Weptos wave energy converter. In Proceedings of the ASME 2012 31st International Conference on Ocean, Offshore and Arctic Engineering, Rio de Janiero, Brazil, 1-6 July 2012; pp. 525-534.

132. Skyner, D.J. Solo Duck Linear Analysis; The University of Edinburgh: Edinburgh, UK, 1987.

133. Babarit, A.; Clément, A.H.; Gilloteaux, J.C. Optimization and time-domain simulation of the SEAREV wave energy converter. In Proceedings of the ASME 2005 24th International Conference on Offshore Mechanics and Arctic Engineering, Halkidiki, Greece, 12-17 June 2005; pp. 703-712. 
134. Folley, M.; Whittaker, T.J.T.; Henry, A. The effect of water depth on the performance of a small surging wave energy converter. Ocean Eng. 2007, 34, 1265-1274. [CrossRef]

135. Flocard, F.; Finnigan, T.D. Experimental investigation of power capture from pitching point absorbers. In Proceedings of the Eight European Wave and Tidal Energy Conference, Upsalla, Sweden, 7-10 September 2009.

136. Henry, A.; Doherty, K.; Cameron, L.; Whittaker, T.; Doherty, R. Advances in the design of the Oyster wave energy converter. In Proceedings of the RINA Marine and Offshore Energy Conference, London, UK, 21-23 April 2010.

137. Pecher, A.; Kofoed, J.P.; Larsen, T. Design specifications for the Hanstholm WEPTOS wave energy converter. Energies 2012, 5, 1001-1017. [CrossRef]

138. Pecher, A.; Kofoed, J.P.; Larsen, T. The extensive R\&D behind the Weptos WEC. Renew. Energ. Offshore 2015, $1,351$.

139. Kofoed, J.P.; Tetu, A.; Ferri, F.; Margheritini, L.; Sonalier, N.; Larsen, T. Real Sea Testing of a Small Scale Weptos WEC Prototype. In Proceedings of the ASME 2018 37th International Conference on Ocean, Offshore and Arctic Engineering, Madrid, Spain, 17-22 June 2018.

140. Margheritini, L.; Kofoed, J.P. Weptos Wave Energy Converters to Cover the Energy Needs of a Small Island. Energies 2019, 12, 423. [CrossRef]

141. Renzi, E.; Dias, F. Resonant behaviour of an oscillating wave energy converter in a channel. J. Fluid Mech. 2012, 701, 482-510. [CrossRef]

142. Pecher, A.; Kofoed, J.P.; Espedal, J.; Hagberg, S. Results of an experimental study of the langlee wave energy converter. In Proceedings of the Twentieth International Offshore and Polar Engineering Conference, Beijing, China, 20-25 June 2010.

143. Angelelli, E.; Zanuttigh, B.; Kofoed, J.P.; Glejbøl, K. Experiments on the WavePiston, Wave Energy Converter. In Proceedings of the EWTEC 2011, Southampton University, Southampton, UK, 5-9 September 2011.

144. Cordonnier, J.; Gorintin, F.; De Cagny, A.; Clément, A.H.; Babarit, A. SEAREV: Case study of the development of a wave energy converter. Renew. Energy 2015, 80, 40-52. [CrossRef]

145. Evans, D.V.; de O Falcao, A.F. Hydrodynamics of Ocean Wave Energy Utilization; Springer: Berlin, Germany, 1986; pp. 51-55.

146. Kofoed, J.P.; Frigaard, P.; Friis-Madsen, E.; Sørensen, H.C. Prototype testing of the wave energy converter wave dragon. Renew. Energy 2006, 31, 181-189. [CrossRef]

147. Margheritini, L.; Vicinanza, D.; Frigaard, P. Hydraulic characteristics of seawave slot-cone generator pilot plant at Kvitsøy (Norway). In Proceedings of the 7th European Wave Tidal Energy Conference, Porto, Portugal, 11-13 September 2007; pp. 1-9.

148. Margheritini, L.; Vicinanza, D.; Frigaard, P. SSG wave energy converter: Design, reliability and hydraulic performance of an innovative overtopping device. Renew. Energy 2009, 34, 1371-1380. [CrossRef]

149. Parmeggiani, S.; Chozas, J.F.; Pecher, A.; Friis-Madsen, E.; Sørensen, H.C.; Kofoed, J.P. Performance assessment of the wave dragon wave energy converter based on the EquiMar methodology. In Proceedings of the 9th European Wave and Tidal Energy Conference, Napoli, Italy, 5-9 September 2011.

150. Pecher, A. Performance Evaluation of Wave Energy Converters. Ph.D. Thesis, Department of Civil Engineering, Aalborg University, Aalborg, Denmark, 2012. Available online: https://vbn.aau.dk/en/ publications/performance-evaluation-of-wave-energy-converters-2 (accessed on 11 November 2018).

151. Chozas, J.F.; Kofoed, J.P.; Jensen, N.E.H. User Guide-COE Calculation Tool for Wave Energy Converters: Ver. 1.6-April 2014, 1st ed.; DCE Technical Reports, No. 161; Department of Civil Engineering, Aalborg University: Aalborg, Denmark, 2014.

152. Dalton, G.J.; Alcorn, R.; Lewis, T. A 10 year installation program for wave energy in Ireland: A case study sensitivity analysis on financial returns. Renew. Energy 2012, 40, 80-89. [CrossRef]

153. Weiss, J.C.; Boehlert, B.B.; Baxter, J.R. Fiscal Cost-Benefit Analysis to Support the Rulemaking Process for 30 CFR 285 Governing Alternative Energy Production and Alternate Uses of Existing Facilities on the Outer Continental Shelf; OCS Study MMS 2007-050; Technical Report; USDOI/MMS, Offshore Environmental Division: Herndon, VA, USA, 2008; p. 101.

154. Callaghan, J.; Boud, R. Future Marine Energy. Results of the Marine Energy Challenge: Cost Competitiveness and Growth of Wave and Tidal Stream Energy; Carbon Trust: London, UK, 2006. 
155. Bedard, R.; Hagerman, G.; Siddiqui, O. System Level Design, Performance and Costs for San Francisco California Pelamis Offshore Wave Power Plant; EPRI: San Francisco, CA, USA, 2004.

156. Allan, G.; Gilmartin, M.; McGregor, P.; Swales, K. Levelised costs of Wave and Tidal energy in the UK: Cost competitiveness and the importance of "banded" Renewables Obligation Certificates. Energy Policy 2011, 39, 23-39. [CrossRef]

157. De Andres, A.; MacGillivray, A.; Roberts, O.; Guanche, R.; Jeffrey, H. Beyond LCOE: A study of ocean energy technology development and deployment attractiveness. Sustain. Energy Technol. Assess. 2017, 19, 1-16. [CrossRef]

158. Contestabile, P.; Di Lauro, E.; Buccino, M.; Vicinanza, D. Economic assessment of Overtopping BReakwater for Energy Conversion (OBREC): A case study in Western Australia. Sustainability 2016, 9, 51. [CrossRef]

159. De Andres, A.; Medina-Lopez, E.; Crooks, D.; Roberts, O.; Jeffrey, H. On the reversed LCOE calculation: Design constraints for wave energy commercialization. Int. J. Mar. Energy 2017, 18, 88-108. [CrossRef]

160. Frost, C.; Findlay, D.; Macpherson, E.; Sayer, P.; Johanning, L. A model to map levelised cost of energy for wave energy projects. Ocean Eng. 2018, 149, 438-451. [CrossRef]

161. Castro-Santos, L.; Garcia, G.P.; Estanqueiro, A.; Justino, P.A. The Levelized Cost of Energy (LCOE) of wave energy using GIS based analysis: The case study of Portugal. Int. J. Electr. Power Energy Syst. 2015, 65, 21-25. [CrossRef]

162. Haces-Fernandez, F.; Li, H.; Ramirez, D. Assessment of the Potential of Energy Extracted from Waves and Wind to Supply Offshore Oil Platforms Operating in the Gulf of Mexico. Energies 2018, 11, 1084. [CrossRef]

163. Haces-Fernandez, F.; Li, H.; Jin, K. INVESTIGATION INTO THE POSSIBILITY OF EXTRACTING WAVE ENERGY FROM THE TEXAS COAST. Int. J. Energy Clean Environ. 2019, 20, 23-41. [CrossRef]

(C) 2019 by the authors. Licensee MDPI, Basel, Switzerland. This article is an open access article distributed under the terms and conditions of the Creative Commons Attribution (CC BY) license (http://creativecommons.org/licenses/by/4.0/). 